\title{
Deep-water Holothuroidea (Echinodermata) collected during the TALUD cruises off the Pacific coast of Mexico, with the description of two new species
}

\author{
Holothuroidea (Echinodermata) de mar profundo recolectadas durante las campañas TALUD \\ frente a la costa del Pacífico mexicano, con la descripción de dos especies nuevas
}

\author{
Claude Massin ${ }^{1}$ and Michel E. Hendrickx ${ }^{2 *}$ \\ ${ }^{I}$ Department of Recent Invertebrates, Royal Belgian Institute of Natural Sciences, Rue Vautier 29, Brussels, B-1000, Belgium. \\ ${ }^{2}$ Unidad Académica Mazatlán, Instituto de Ciencias del Mar y Limnología, Universidad Nacional Autónoma de México, PO Box 811,82000 Mazatlán, \\ Sinaloa, México. \\ *Correspondent: michel@ola.icmyl.unam.mx
}

\begin{abstract}
Research cruises aboard the R/V "El Puma" were organized to collect deep-water benthic and pelagic specimens off the Pacific coast of Mexico. Seventy four specimens of Holothuroidea were collected off the Pacific coast of Mexico in depths of 377-2 $200 \mathrm{~m}$. The collection includes representatives of 5 of the 6 orders of Holothuroidea, 3 Dendrochirotida, 2 Dactylochirotida, 2 Aspidochirotida, 4 Elasipodida and 2 Molpadiida. Apodida were not represented. Of the 13 species recognized, 11 were identified to species level and 2, belonging to the genera Ypsilocucumis Panning, 1949, and Mitsukuriella Heding and Panning, 1954, are new to science. Five species represent new geographic or depth records. A list of Mexican localities previously and newly reported for each species are plotted on distribution maps. Environmental data, i.e., depth, temperature, and dissolved oxygen measured at the bottom level during the survey are provided. When compared with other areas of the world, the reduced number of specimens collected during this survey could be linked to the limiting effect of the Pacific Mexico Oxygen Minimum Zone. An updated checklist of species of Holothuroidea recorded below $350 \mathrm{~m}$ depth along the Pacific coast of Mexico is also provided totaling 31 species: 13 of these occur in the California Current area, 20 in the Gulf of California, and 15 (16) along the SW coast of Mexico.
\end{abstract}

Key words: Holothuroidea, deep-water community, continental slope, East Pacific, Mexico, new species.

Resumen. Una serie de campañas oceanográficas fue organizada a bordo del B/O "El Puma", frente a las costas del Pacífico mexicano con el propósito de recolectar ejemplares de la fauna bentónica y pelágica de aguas profundas. La recolección incluyó representantes de 5 de los 6 órdenes de Holothuroidea, i.e., 3 Dendrochirotida, 2 Dactylochirotida, 2 Aspidochirotida, 4 Elasipodida y 2 Molpadiida. Los Apodida no están representados. De las 13 especies capturadas por debajo de los $350 \mathrm{~m}$ de profundidad (377-2 $200 \mathrm{~m}), 11$ fueron identificadas hasta especie y 2 pertenecientes a los géneros Ypsilocucumis Panning, 1949, y Mitsukuriella Heding y Panning, 1954, son nuevas para la ciencia. El material examinado comprende 74 ejemplares. Las localidades previas y nuevas registradas para cada especie recolectada están compiladas para el Pacífico mexicano en mapas de distribución. Se proporciona información acerca de las condiciones de captura de cada especie (temperatura y oxígeno disuelto). Comparativamente con otras áreas del mundo, el número reducido de organismos recolectados durante el estudio podría estar relacionado con la presencia de una zona del mínimo de oxígeno a lo largo del Pacífico mexicano. Se anexa una lista actualizada de las especies de Holothuroidea registradas en profundidades mayores a $350 \mathrm{~m}$ frente a la costa del Pacífico mexicano. En total, 31 especies están registradas: 13 en el área de la corriente de California, 20 en el golfo de California y 15 (16) a lo largo de la costa SO de México.

Palabras clave: Holothuroidea, comunidad de aguas profundas, talud continental, nuevas especies, Pacífico este, México.

\section{Introduction}

Deep-sea macroinvertebrate communities are characterized by high diversity values (Hessler and Sanders, 1967; Sanders and Hessler, 1969; Grassle, 1989;

Recibido: 15 abril 2010; aceptado: 28 enero 2011
Smith et al., 1998). In areas where the oxygen-minimum zone (OMZ) intercepts the continental slope, anoxic and severely hypoxic benthic fringes are species-poor, but in even deeper water the hypoxic zone is species-rich. In the OMZ, depth and dissolved oxygen concentration are the most important factors affecting deep water community composition (Rosenberg et al., 1983; Levin and Gage, 1998; Rogers, 2000; Hendrickx, 2001; Levin et al., 2001; 
McClain, 2004; Méndez, 2006; Zamorano et al., 2006) and species size (Rex and Etter, 1998; McClain and Rex, 2001; Olabarria and Thurston, 2003, 2004).

Study of Mexican echinoderms in the East Pacific started with the contributions of A.E. Verrill, who studied material collected along the west coast of America, including specimens from the area of La Paz (Verrill, 1868), Cabo San Lucas and the Gulf of California (Verrill, 1870, 1871b). He also reviewed large collections obtained during surveys covering much larger geographic areas (e.g., Verrill, 1867, 1871a), and described several new taxa. The Holothuroidea collected by the "Albatross" (west coast of America, from Peru to California, including Mexico) were studied by Ludwig $(1893,1894)$ and H.L. Clark (1913, 1920, 1923). Ludwig's monograph (1894) is by far the most important contribution for deep-water Holothuroidea in the region, with a total of 21 species described that occur below $350 \mathrm{~m}$ depth. Several other contributions complement the study of deep-water Holothuroidea in the central eastern Pacific, with the description of 14 species: Müller (1850) described 1 new species, Mitsukuri (1912) 1, H.L. Clark (1913, 1920, 1923) 5, Deichmann (1938a) 1, Cherbonnier (1941) 1, Belyaev (1971) 2, Hansen (1975) 2, and Pawson (1983) 1. Other contributions, essentially by Deichmann (1937, 1938a, 1938b, 1938c), increased the number of deep-water species known to the region.

Several papers, principally based on literature, present compilation lists of holothurians from the central eastern Pacific (see Table 2). Parker (1964) listed material collected in the Gulf of California and in several other sites along the west coast of Mexico, including 12 species of deep-water Holothuroidea. Bergen (1980) listed material collected in Southern California that includes 5 deep-water species. Maluf (1988) compiled thoroughly all the information on Central eastern Pacific echinoderms (list of species, depth distribution, geographical range). According to Maluf (1988), there were 55 species of Holothuroidea occurring below $350 \mathrm{~m}$ depth. Two deep-water species cited in the literature and of dubious status were also cited by Maluf (1988: 167) in an annex but were not included in her general analysis: Achlyonice ecalcarea Théel, 1879 (off Baja California, $1598 \mathrm{~m}$ ) and Bathyplotes hancocki Domantay, 1961 (Southern California and Gulf of California). Another species, Penagione leander Pawson and Foell, 1986, an abyssal benthopelagic sea cucumber, was omitted by Maluf (1988) and therefore increases the list of species known from the Central eastern Pacific to 56. Of these 56 species, 5 were originally described from other regions of the world and later reported for the Central eastern Pacific: Synallactes ishikawai Mitsukuri, 1912 (now a junior synonym of S. sagamiensis Augustin, 1908), from Japan; Leptosynapta albicans (Selenka, 1867), from the North Atlantic; Rynkatorpa duodactyla (H.L. Clark, 1907) (as Protankyra duodactyla), from the NW Pacific; Ceraplectana trachyderma H.L. Clark, 1907, from the NW Pacific; and Molpadia musculus Risso, 1826, from the Mediterranean.

Maluf (1991) proposed a checklist of echinoderms reported from the Galapagos Islands, including 38 Holothuroidea, 16 with records below $350 \mathrm{~m}$ depth. Lambert (1996) presented a recapitulation table with distribution, habitat and morphological data for all 8 species of Psolidium known from the eastern Pacific. Of these 8 species, only 2 (P. panamense Ludwig, 1894, and $P$. gracile Ludwig, 1894) occur deeper than $350 \mathrm{~m}$ (at $2323 \mathrm{~m}$, both at the same and unique known locality, in the Gulf of Panama), and both were cited by Maluf (1988). Solís-Marín et al. (1997) presented a compilation of species of echinoderms known from the Bay of La Paz. Mostly based on literature records, the list includes 27 Holothuroidea with 3 species occurring below $500 \mathrm{~m}$. Further north, a large series of exploratory surveys were performed off the coast of California and Oregon, USA. Echinoderms, particularly Holothuroidea, were often identified to species level. A review of the information available was presented by Nybakken et al. (1998), who also reported on 13 species of Holothuroidea collected or observed by either a beam trawl or a camera sled off central California, many of which were previously reported for Mexico.

Additional information related to deep-water Holothuroidea from off the Galapagos was provided by Pawson and Ahearn (2001). More recently, Maluf and Brusca (2005) have reported 57 species of Holothuroidea for the Gulf of California, most from shallow water, and only 9 deep-water ( $>350 \mathrm{~m}$ depth) species are included in their list. Solís-Marín et al. (2005) published a compilation of echinoderm species from the Gulf of California. This list, based exclusively on records verified in the Dra. María Elena Caso Muñoz (Universidad Autónoma de México, México City) and in the Smithsonian Institution (Washington D.C.) echinoderms collections, includes 45 species of Holothuroidea from all kinds of habitats. Subsequently, Honey-Escandón et al. (2008) presented a list of species for the Mexican Pacific (i.e., excluding the Gulf), based on the same collections, with 46 species of Holothuroidea, and Solís-Marín et al. (2009) summarized our present knowledge of the Gulf of California Holothuroidea in a monograph that includes 55 species.

Many contributions to our knowledge of Mexican echinoderms were authored by M. E. Caso. Because she worked exclusively on intertidal and shallow-water holothurians (see among others Caso 1964, 1966, 1968), her contributions will rarely be cited in this study. 


\section{Materials and methods}

Holothuroidea were collected between 377 and 2200 $\mathrm{m}$ depth on the continental slope along the Pacific coast of Mexico using an Agassiz dredge (ca $2.7 \mathrm{~m}$ width) and a benthic sledge ( $2.35 \mathrm{~m}$ width, $0.95 \mathrm{~m}$ high) equipped with a collecting net of ca $5.5 \mathrm{~cm}(21 / 4$ ") stretched mesh aperture and an internal net with a ca $2.0 \mathrm{~cm}\left(3 / 4^{\prime \prime}\right)$ stretched mesh aperture. A total of 13 cruises were organized in the Gulf of California and along SW Mexico, south of Banderas Bay, from 1989 to 2008. Specimens of Holothuroidea were collected during 9 cruises: TALUD III, September 1991; TALUD VI, March 2001; TALUD VII, June 2001; TALUD VIII, April 2005; TALUD IX, November 2005; TALUD X, February 2007; TALUD XI, June 2007; TALUD XII, March-April 2008; and TALUD XIII, January 2009. Positional coordinates for each station were plotted using a GPS navigation system. Depth was measured with an EdoWestern, analog recorder (TALUD III-VIII) or a digital recorder (TALUD IX-XIII). Epibenthic water temperature was measured with a Seabird CTD, and dissolved oxygen content was measured by the Winkler method (all cruises) and with a probe attached to the CTD (TALUD VIII-XIII). Holothuroidea were fixed on board with a $4 \%$ formaldehyde sea water solution, washed with tap water and preserved in $70 \%$ ethanol. In the systematic section below, a restricted synonymy including the prime synonym, references to new combination or reviews, and references for the Pacific coast of Mexico are included for each species, together with comments and additional data related to their distribution and ecology. The material examined herein is deposited in the Regional Collection of Invertebrates (EMU), ICML, UNAM, Mazatlán, Sinaloa, Mexico, in the collection of Holothuroidea at the Royal Belgian Institute of Natural Sciences (IG/HOL/RBINS), Brussels, Belgium, and in the Colección Nacional de Equinodermos "Dra. María Elena Caso" (ICML-UNAM), in México D.F., Mexico. Material examined also include 2 lots received on loan from the Scripps Institution of Oeanography, University of California San Diego (SIO, UCSD), La Jolla, USA, and a series of ossicle preparations from the Zoology Museum of Hamburg (ZMH), Hamburg, Germany. Other abbreviations used are: L, total length; St., sampling station: id.; identificator; coll., collector. Based primarily on Maluf (1988) contribution, a list of all species with at least 1 record within Mexican waters of the Pacific Ocean was established (Table 1). In most cases the records used by Maluf were checked in the original literature. Literature records posterior to 1988 or based on the material collected during the TALUD cruises were incorporated in this list. The sources of these records are indicated in table 1.

\section{Results}

Generality and abiotic factors. During the TALUD cruises, a total of 135 localities were sampled with benthic sledges and Holothuroidea were captured in 25 of these. No specimens of Holothuroidea were caught during the TALUD I, II, IV and V cruises. A total of 13 species represented by 74 specimens were collected. Eleven were identified to species level, 2 of these recognized as new species. The collection includes representatives of 5 of the 6 orders of Holothuroidea, i.e., 3 Dendrochirotida, 2 Dactylochirotida, 2 Aspidochirotida, 4 Elasipodida and 2 Molpadiida. Apodida were not represented. In 23 stations only 1 species was collected. A maximum of 3 species were found in a single station and 2 in another. All species considered, the material obtained in this survey was caught in a depth range of 377 to $2200 \mathrm{~m}$, and in epibenthic temperature and dissolved oxygen ranges of 2.0 to 10.52 ${ }^{\circ} \mathrm{C}$ and $<0.05$ to $2.14 \mathrm{ml} \mathrm{O}_{2} / 1$, respectively (Table 1 ).

\section{Descriptions}

Class Holothuroidea de Blainville, 1834

Order Dendrochirotida Grube, 1840

Family Cucumariidae Ludwig, 1894

Genus Abyssocucumis Heding, 1942

Abyssocucumis albatrossi (Cherbonnier, 1941)

Figs. 1 A-F, 2

Cucumaria albatrossi Cherbonnier, 1941: 93-103, fig. 2, fig. 3 a-h, i, k-m.

Abyssocucumis albatrossi; Cherbonnier, 1947: 462; Panning, 1949: 454; Madsen, 1955: 165, 167; Carney and Carey, 1976: 69; Maluf, 1988: 92, 155; Nybakken et al., 1998: 1778.

Cucumaria abyssorum; Ludwig, 1894; 122, pl. XIII, figs. 1-5; Ludwig and Heding, 1935: 179, textfig. 42.

Staurocucumis abyssorum; Hansen, 1988: 302, Fig. 1; Solís-Marín et al., 2009: 84, pl. 17A-E.

Non: Cucumaria abyssorum Théel, 1886: 66.

Material examined. One specimen $(\mathrm{L}=66 \mathrm{~mm})$, TALUD XIII, St. 37 (EMU-8630).

Body cylindrical, $66 \mathrm{~mm}$ long, $25 \mathrm{~mm}$ across, slightly tapering at both extremities. Mouth and anus terminal. Tentacles fully retracted. Colour in alcohol grayish to black. Body wall gritty to the touch, parchment like, 0.7 $\mathrm{mm}$ thick. Tube feet only in the ambulacral zone aligned in 2 rows. Ossicles of the body wall as cross-shaped 
Table 1. Sampling stations of the TALUD cruises where specimens of Holothuroidea were collected and list of species per station. Position, depth, and epibenthic water temperature and dissolved oxygen concentration are indicated for each station. Precision of data may vary according to the method used during the survey

\begin{tabular}{|c|c|c|c|c|c|c|c|}
\hline Cruise & Station & Species & Position & Date & $\begin{array}{l}\text { Depth } \\
(m)\end{array}$ & $\begin{array}{l}\text { Temp. } \\
{ }^{\circ} \mathrm{C}\end{array}$ & $\begin{array}{c}\text { Oxygen } \\
\mathrm{ml} / \mathrm{l}\end{array}$ \\
\hline TALUD III & St. 14B & Molpadia musculus & $24^{\circ} 39^{\prime} 12^{\prime \prime} \mathrm{N}, 108^{\circ} 37^{\prime} 54^{\prime \prime} \mathrm{W}$ & 8-Sep-1991 & $1188-1208$ & ND & 0.4 \\
\hline TALUD VI & St. 25 & Molpadia intermedia & $24^{\circ} 51^{\prime} 41^{\prime \prime} \mathrm{N}, 108^{\circ} 57^{\prime} 53^{\prime \prime} \mathrm{W}$ & 16-Mar-2001 & $830-850$ & ca 5.0 & 0.22 \\
\hline TALUD VI & St. 26 & Ypsilocucumis californiae & $24^{\circ} 56^{\prime} 17^{\prime \prime} \mathrm{N}, 109^{\circ} 6^{\prime} 39^{\prime \prime} \mathrm{W}$ & 16-Mar-2001 & $1190-1270$ & 3.7 & 1.4 \\
\hline TALUD VIII & St. 3 & Pannychia moseleyi & $24^{\circ} 32^{\prime} 36^{\prime \prime} \mathrm{N}, 109^{\circ} 30^{\prime} 30^{\prime \prime} \mathrm{W}$ & 16-Apr-2005 & 1100 & 3.0 & 0.39 \\
\hline TALUD VIII & St. 11 & $\begin{array}{l}\text { Ypsilocucumis californiae } \\
\text { Synallactes alexandri } \\
\text { Pannychia moseleyi }\end{array}$ & $24^{\circ} 54^{\prime} 24^{\prime \prime} \mathrm{N}, 110^{\circ} 25^{\prime} 30^{\prime \prime} \mathrm{W}$ & 17-Apr-2005 & 920 & 5 & 0.2 \\
\hline TALUD VIII & St. 16 & $\begin{array}{l}\text { Ypsilocucumis californiae } \\
\text { Synallactes virgulasolida }\end{array}$ & $25^{\circ} 24^{\prime} 48^{\prime \prime} \mathrm{N}, 110^{\circ} 34^{\prime} 48^{\prime \prime} \mathrm{W}$ & 18-Apr-2005 & 1030 & 5 & 0.2 \\
\hline TALUD VIII & St. 20 & Dendrochirotida sp. und. & $25^{\circ} 56^{\prime} 54^{\prime \prime} \mathrm{N}, 110^{\circ} 45^{\prime} 0^{\prime \prime} \mathrm{W}$ & 19-Apr-2005 & 1150 & 4 & 0.30 \\
\hline TALUD VIII & St. 22 & Elasipodida sp. und. & $26^{\circ} 03^{\prime} 42^{\prime \prime} \mathrm{N}, 110^{\circ} 21^{\prime} 18^{\prime \prime} \mathrm{W}$ & 19-Apr-2005 & 2200 & 2.0 & 1.27 \\
\hline TALUD IX & St. 10 & Pannychia moseleyi & $24^{\circ} 56^{\prime} 24^{\prime \prime} \mathrm{N}, 110^{\circ} 16^{\prime} 42^{\prime \prime} \mathrm{W}$ & 12-Nov-2005 & $969-1225$ & 3.6 & 0.11 \\
\hline TALUD IX & St. 16 & Molpadia musculus & $25^{\circ} 23^{\prime} 48^{\prime \prime} \mathrm{N}, 110^{\circ} 36^{\prime} 42^{\prime \prime} \mathrm{W}$ & 13-Nov-2005 & $997-1021$ & 4.6 & 0.15 \\
\hline TALUD IX & St. 17 & Psolidium gracile & $25^{\circ} 20^{\prime} 48^{\prime \prime} \mathrm{N}, 110^{\circ} 46^{\prime} 30^{\prime \prime} \mathrm{W}$ & 13-Nov-2005 & $826-836$ & 5.75 & $<0.05$ \\
\hline TALUD X & St. 3 & $\begin{array}{l}\text { Ypsilocucumis californiae } \\
\text { Psolidium gracile }\end{array}$ & $28^{\circ} 16^{\prime} 40^{\prime \prime} \mathrm{N}, 112^{\circ} 35^{\prime} 10^{\prime \prime} \mathrm{W}$ & 9-Feb-2007 & $377-379$ & 10.52 & 1.05 \\
\hline TALUD X & St. 9 & Mitsukuriella unusordo & $27^{\circ} 52^{\prime} 51^{\prime \prime} \mathrm{N}, 112^{\circ} 15^{\prime} 53^{\prime \prime} \mathrm{W}$ & 10-Feb-2007 & $1205-1215$ & 3.77 & 0.32 \\
\hline TALUD XI & St.1 & Psolidium gracile & $16^{\circ} 52^{\prime} \mathrm{N}, 100^{\circ} 20^{\prime} \mathrm{W}$ & 7-Jun-2007 & $740-790$ & 5.9 & $<0.05$ \\
\hline TALUD XII & St. 5 & Ypsilothuria bitentaculata & $16^{\circ} 58^{\prime} 17^{\prime \prime} \mathrm{N}, 100^{\circ} 55^{\prime} 12^{\prime \prime} \mathrm{W}$ & 28-Mar-2008 & $1925-1977$ & 2.6 & 1.43 \\
\hline TALUD XII & St. 8 & Elasipodida sp. und. & 1704’09”N, 101³9’16”W & 29-Mar-2008 & $1880-1940$ & 2.35 & 1.99 \\
\hline TALUD XII & St. 9 & Laetmogone scotoeides & $17^{\circ} 10^{\prime} 15^{\prime \prime} \mathrm{N}, 101^{\circ} 37^{\prime} 23 \mathrm{~W}$ & 28-Mar-2008 & $1392-1420$ & 3.28 & 1.01 \\
\hline TALUD XII & St. 10 & Laetmogone scotoeides & $17^{\circ} 11^{\prime} 18^{\prime \prime} \mathrm{N}, 101^{\circ} 28^{\prime} 30 \mathrm{~W}$ & 29-Mar-2008 & $1180-1299$ & 3.73 & 0.68 \\
\hline TALUD XII & St. 15 & Benthodytes cf. sanguinolenta & $17^{\circ} 25^{\prime} 33^{\prime \prime} \mathrm{N}, 102^{\circ} 07^{\prime} 20^{\prime \prime} \mathrm{W}$ & 30-Mar-2008 & $2015-2080$ & 2.16 & 2.14 \\
\hline TALUD XII & St. 25 & Pannychia moseleyi & $18^{\circ} 26^{\prime} 45^{\prime \prime} \mathrm{N}, 104^{\circ} 16^{\prime} 10^{\prime \prime} \mathrm{W}$ & 1-Apr-2008 & $1858-1879$ & 2.45 & 1.38 \\
\hline TALUD XII & St. 27 & Psolus aff. squamatus & $18^{\circ} 40^{\prime} 28^{\prime \prime} \mathrm{N}, 104^{\circ} 35^{\prime} 51^{\prime \prime} \mathrm{W}$ & 2-Apr-2008 & $1040-1095$ & 4.26 & 0.26 \\
\hline TALUD XII & St. 28 & Psolus aff. squamatus & $18^{\circ} 50^{\prime} 19^{\prime \prime} \mathrm{N}, 104^{\circ} 34^{\prime} 14 \mathrm{~W}$ & 2-Apr-2008 & $1101-1106$ & 4.25 & 0.36 \\
\hline TALUD XII & St. 29 & Pannychia moseleyi & $19^{\circ} 19^{\prime} 37^{\prime \prime} \mathrm{N}, 105^{\circ} 26^{\prime} 20^{\prime \prime} \mathrm{W}$ & 2-Apr-2008 & $1609-1643$ & 2.82 & 1.38 \\
\hline TALUD XIII & St. B & Elasipodida sp. und. & $26^{\circ} 17^{\prime} 04^{\prime \prime} \mathrm{N}, 110^{\circ} 27^{\prime} 53^{\prime \prime} \mathrm{W}$ & 13-Jan-2009 & $1295-1330$ & 3.62 & 0.87 \\
\hline TALUD XIII & St. 37 & Abyssocucumis albatrossi & $25^{\circ} 59^{\prime} 30^{\prime \prime} \mathrm{N}, 110^{\circ} 19^{\prime} 21^{\prime \prime} \mathrm{W}$ & 15-Jan-2009 & $2056-2195$ & 2.56 & 1.68 \\
\hline
\end{tabular}


Table 2. Species (total 31) of deep-water (> $350 \mathrm{~m}$ depth) Holothuroidea occuring off the coast of Mexico (northernmost limit set at $32^{\circ} 28^{\prime} 16^{\prime \prime} \mathrm{N}$; southernmost limit set at $14^{\circ} 32^{\prime} 27^{\prime} \mathrm{N}$ ), including the California Current area (CC), the Gulf of California (GC), the area of souwestern Mexico, south of Banderas Bay (SWM), and the offshore islands (OI). Data used in the table were taken from the following sources: PA, Parker (1964); MA, Maluf (1988); SO1, Solis-Marín et al. (1997); SO2, Solis-Marín et al. (2005); SO3, Solis-Marín et al. (2009); MB, Maluf and Brusca (2005); HE HoneyEscandón et al. (2008); PS, present study. Boldface: species collected during the TALUD cruises. (?) Dubious record. The unidentifiable specimens collected during the TALUD cruises are not included in this list (see text for further comments). For convenience species are listed following Maluf's (1988) sequence

\begin{tabular}{|c|c|c|c|c|}
\hline Species & $C C$ & $G C$ & $S W M$ & OI \\
\hline Psolidium gracile Ludwig, 1894 & & PS & PS & \\
\hline Psolus cf. squamatus (O.F. Müller, 1776) & PA PS & MA & PS & \\
\hline Abyssocucumis abyssorum (Théel, 1886) (1) & PA MA HE & MA MB SO1 & PA MA HE & \\
\hline Abyssocucumis albatrossi (Cherbonnier, 1941) (2) & & PS SO3 & & \\
\hline Mitsukuriella unusordo sp. nov. & & PS & & \\
\hline Ypsilocucumis californiae sp. nov. & & PS & & \\
\hline Ypsilothuria bitentaculata (Ludwig, 1893) (3) & PA MA & MA MB & MA PS & \\
\hline Paelopatides confundens Théel, 1886 & & MA MB & & \\
\hline Pseudostichopus mollis Théel, 1886 & & PA MA MB & PA MA & \\
\hline Bathyplotes sp. & MA & $\mathrm{PA}$ & & \\
\hline Synallactes sagamiensis Augustin, 1908 (4) & & & PA MA & \\
\hline Synallactes alexandri Ludwig, 1894 & & PS & & \\
\hline Synallactes virgulasolida Massin and Hendrickx, 2010 & & PS & & \\
\hline Oneirophanta mutabilis mutabilis Théel, 1979 & PA & & PA MA & \\
\hline Laetmogone scotoeides (H.L. Clark, 1913) & MA & & PS & \\
\hline Laetmogone wyvillethomsoni Théel, 1879 & MA & & & \\
\hline Pannychia moseleyi Théel, 1882 & MA & MA MB SO1 SO2 SO3 PS & MA PS & \\
\hline Psychronaetes hanseni Pawson, 1983 & & & & MA (Clarion) \\
\hline Benthodytes sanguinolenta Théel, 1882 (5) & PA MA HE & & PS & \\
\hline Psychropotes longicauda Théel, 1882 (6) & PA MA & & PA MA & \\
\hline Peniagone intermedia Ludwig, 1894 & & & MA(?) & \\
\hline Peniagone papillata Hansen, 1975 & & & MA & \\
\hline Peniagone sp. & & $\mathrm{PA}$ & & \\
\hline Scotoplanes clarki Hansen, 1975 & & $\mathrm{SO} 3$ & & \\
\hline Scotoplanes globosa (Théel, 1879) & MA & & & \\
\hline Leptosynapta albicans (Selenka, 1867) & & & & MA (Socorro) \\
\hline Molpadia granulata (Ludwig, 1894) (7) & & PA MA MB & & \\
\hline
\end{tabular}


Table 2. Continues

\begin{tabular}{|c|c|c|c|c|}
\hline Species & $C C$ & $G C$ & $S W M$ & $O I$ \\
\hline Molpadia intermedia (Ludwig, 1894) & MA HE & MA MB SO1 SO3 PS & & \\
\hline Molpadia musculus Risso, 1826 & MA HE & PA MA SO1 SO3 MB PS & PA MA & \\
\hline Heldingia californica (Ludwig, 1894) (8) & & MA SO1 SO3 & & \\
\hline Paracaudina chilensis (J. Müller, 1850) & & MA SO2 & MA & \\
\hline
\end{tabular}

(1) Also cited in the genus Staurocucumis.

(2) See text for further details.

(3) Previously in the genus Sphaerothuria.

(4) Cited as S. ishikawai f. ind.

(5) Not cited by Maluf and Brusca (2005).

(6) Cited by Parker (1964) as $P$. dubiosa Ludwig, 1894, and P. raripes Ludwig, 1894, both junior synonyms of $P$. longicauda.

(7) Cited by Parker (1964) as M. granulosa.

(8) Also cited in the genus Caudina.

ossicles, 270-330 $\mu \mathrm{m}$ long, very spiny, with or without perforation at the extremities of the arms (Fig. 1A). Most of these cross-shaped ossicles have 4 arms, a few have 3 or 5 arms. In the tube feet same kind of ossicles (Fig. 1B, C), somewhat larger (up to $450 \mu \mathrm{m}$ ), the most common with 2 long and 2 short arms (Fig.1B). Extremities of these arms multi-perforated (Fig. 1C). In the tentacles 2 kinds of rods: very thin, with strong spines on 1 side (Fig.1D), or with a central apophysis, $180-250 \mu \mathrm{m}$ long, and large straight to $\mathrm{V}$-shaped rods, smooth or spiny, up to $600 \mu \mathrm{m}$ long, with a central apophysis (Fig. 1E-F),

\section{Remarks}

The present specimen fits particularly well with the detailed description of Abyssocucumis albatrossi given by Cherbonnier (1941).The spiny arms of the cross-shaped ossicles are characteristic of the species whereas smooth arms are characteristic of Abyssocucumis abyssorum Théel, 1886. Ludwig (1894: pl. XIII, figs. 1-5) illustrated an $A$. albatrossi, but named his material abyssorum. Hansen (1988), who considered albatrossi a synonym of abyssorum, moved abyssorum to the genus Staurocucumis. Hansen considered that the cross-shaped ossicles are characteristic of the juveniles and disappear in adults to be replaced by perforated plates. However, the $60 \mathrm{~mm}$ long specimen here examined is an adult with a well developed gonad. Ludwig (1894) observed also only cross-shaped ossicles in large specimens (up to $90 \mathrm{~mm}$ long) and no perforated plates. Another argument to sustain the opinion of Hansen (1988) is the fact that among the dendrochirotes (particularly in the genus Staurocucumis) the ossicles become more spiny with increasing body size (Massin, 1994). Indeed, in the paper of Cherbonnier (1941) the $A$. abyssorum (smooth ossicle arms) are small specimens, $<30$ mm long, whereas the $A$. albatrossi (spiny ossicle arms) are large specimens, $60 \mathrm{~mm}$ long. Abyssocucumis abyssorum could thus be the juveniles of $A$. albatrossi. However, this does not fit with the presence of a well developed gonad in both species, whatever the body size (Théel, 1886; Ludwig, 1894; Cherbonnier, 1941). Moreover, small and large specimens of $A$. abyssorum present smooth ossicle arms (Théel, 1886; Ludwig, 1894; Heding, 1942). Spiny or smooth ossicle arms seem to not be related to body size. Consequently, we consider that $A$. albatrossi and $A$. abyssorum are well separated species, both belonging to the genus Abyssocucumis as defined by Heding (1942).

The Staurocucumis abyssorum illustrated by SolísMarín et al. (2009: 84, pl. 17, Fig. B) is, according to us, a specimen of Abyssocucumis albatrossi because of the very spiny arms of the cross-shaped ossicles.

Distribution. Records in Mexico. Known from the type locality (“Albatross" St. 3414, 10¹4'N, 96 28' W) located about $500 \mathrm{~km}$ off the coast of Chiapas, SW Mexico; 4085 m (2 $232 \mathrm{fm}$ ) (Fig. 2). According to Cherbonnier (1941), the 2 specimens he examined had been collected at the "Albatross" St. 3414, located off SW Mexico (above). He also stated, however, that $A$. albatrossi is found in the Gulf 
of Panama $\left(1^{\circ} 05^{\prime} \mathrm{N}, 29^{\circ} 40^{\prime} \mathrm{N}\right)$ and in the Gulf of California $\left(27^{\circ} 34^{\prime} \mathrm{N}, 110^{\circ} 53^{\prime} 40^{\prime \prime} \mathrm{W}\right)$, at $1466-3615 \mathrm{~m}$ depth, but it seems he did not actually examine material from these 2 localities. According to Maluf (1988), A. albatrossi is known only from off Peru (ca $6^{\circ} \mathrm{S}$ ) and from a (doubtful) locality off California (ca $32^{\circ} \mathrm{N}$ ), in depths of 1 585-5 690 $\mathrm{m}$. In addition to the original description by Cherbonnier (1941), Maluf (1988) only cited the reference of Madsen (1955) as sources for the geographic and bathymetric ranges of $A$. albatrossi, and the data provided by her are exactly the same as those provided by Madsen. Although much more detailed than the information provided by Madsen, the compilation presented by Maluf (1988) does not include the Chiapas (type locality) record, which is rather surprising. We were not able, however, to trace the records for California, the Gulf of California and Peru cited by Cherbonnier (1941) and Maluf (1988). Abyssocucumis albatrossi has been reported from Oregon, NE Pacific, in a depth range of ca $2700-4000 \mathrm{~m}$, and appears to dominate the holothurian community below $3000 \mathrm{~m}$ (Carney and Carey, 1976; not cited by Maluf). It was also recently reported by Nybakken et al. (1998) during a survey off central California, but this Californian record could obviously not be used as a source of information by earlier authors. The geographic range of $A$. albatrossi is provisionally set as off Oregon, USA, to off the coast of Chiapas, Mexico, including the central Gulf of California, Mexico (Fig. 2).

Family Psolidae R. Perrier, 1902

Genus Psolus Oken, 1815

Psolus aff. squamatus (O.F. Müller, 1776)

Fig. 2

Holothuria squamata O.F. Müller, 1776: 232.

Cuvieria squamata; Koren, 1845: 211, pls. 2, 3.

Psolus squamatus; Lütken, 1857:14, 69, 81, 104; Ludwig, 1900: 158 (list of citations); Vaney, 1906a: 27, pl. 2, figs. 16a-c, 17a-c; Mitsukuri, 1912: 225, pl. 7, figs. 61, 62, textfig. 42 ( list of citations); Ohshima, 1915: 280; Ekman, 1923: 1-56 (passim), figs. 12-14, 20-24, 26-27, 29-30, 36-37; Bergen, 1980: 275; Imaoka, 1980: 361, figs. 1-9; Maluf, 1988: 88, 152 (in part, probably not the record of $P$. squamatus segregatus Perrier, 1905); Lambert, 1997: 51, figs. 21, 22; Maluf and Brusca, 2005: 343.

Psolus pauper Ludwig, 1894: 139.

Psolus valvatus Östergren, 1904: 659.

Material examined. Two specimens $(\mathrm{L}=68 \mathrm{~mm}$, EMU-8609; L = 64 mm, IG 31487/HOL 1511 RBINS/ HOL/738992), TALUD XII, St. 27. One specimen ( $L=45$ $\mathrm{mm}$ ), TALUD XII, St. 28 (EMU-8610).
Additional material examined. Three specimens (L $=10,16,27 \mathrm{~mm})$, SW of Punta Banda $\left(31^{\circ} 38^{\prime} 18^{\prime \prime} \mathrm{N}\right.$, $116^{\circ} 51^{\prime} 24^{\prime \prime}$ ), Baja California, 12/February/1960, 183458 m (coll. R. Parker: id. E. Deichmann) (SIO, UCSD, SOB1-31-6333). Ossicle preparations from a specimen of Psolus squamatus segregatus, Patagonia (ZMH, E 4170).

Body elongate to nearly rounded. Dorsal surface covered by large overlapping scales; ventral surface thick with a double row of tube feet along the margin. Midventral radius without tube feet or with a few at the front and at the rear. Mouth and anus dorsal, each at the top of a cone covered by irregular, elongated plates. No clearly defined oral or anal valves. Dorsal scales multilayered, 0.6 to 8.0 $\mathrm{mm}$ across, covered or not with rounded or ovoid granules. When present, granules are $150-250 \mu \mathrm{m}$ across, whatever the size of the specimen. In the ventral sole small perforated plates with 2-9 large holes in the smallest specimen and 3-5 in the large specimens. Largest plates with a few knobs. Size of the plates from 150 to $250 \mu \mathrm{m}$ across in small specimens to $130-165 \mu \mathrm{m}$ across in large specimens. Ossicles of tentacles smooth, perforated plates, rounded, triangular or elongated, slightly curved, 100-500 $\mu \mathrm{m}$ long. In the tube feet elongated perforated plates, $160-320 \mu \mathrm{m}$ long; end plate in 1 piece, $240-450 \mu \mathrm{m}$ across.

\section{Remarks}

Vaney (1906a), Ekman (1923), and Deichmann (1941) considered P. squamatus segregatus as a valid species. The characters separating $P$. squamatus from $P$. squamatus segregatus are: ossicles of the ventral sole (large perforated plates, 150-300 $\mu \mathrm{m}$ across, with large holes vs. small massive perforated plates, $75-110 \mu \mathrm{m}$ across, with small holes, respectively) and the size of the dorsal granules $(150-250 \mu \mathrm{m}$ across vs. 330-470 $\mu \mathrm{m}$ across, respectively) (Ekman, 1923: Fig. $33)$. The specimens examined fit particularly well with $P$. squamatus as far as the body size and the general aspect of dorsal and ventral ossicles are concerned. H.L. Clark (1913), studying material from California, came to the same conclusion. However, H.L. Clark (1913), Mortensen (1927), Madsen (in Maluf, 1988), and Madsen and Hansen (1994) considered that the P. squamatus from Norway and the East Pacific are not conspecific. Contrary to the specimens from the Gulf of California, those from Japan show an increase in the number of holes of the ventral perforated plates with increasing body size (Imaoka, 1980). The small specimen from Japan $(\mathrm{L}=41 \mathrm{~mm})$ is very close to the small specimen $(\mathrm{L}=45 \mathrm{~mm})$ from $\mathrm{SW}$ Mexico examined herein (EMU- 
8610), particularly in the ossicles of the tentacles and the tube feet. The species is also reported to be present in the Pacific waters from Japan (Imaoka, 1980) to Patagonia (Pawson, 1969), through Canada (Lambert, 1997). For the specimens from Patagonia, R. Perrier (1905) erected the variety segregatus. Ekman (1923) and Deichmann (1941) consider that this variety extends from Patagonia to the Bering Sea. According to Ekman (1923) and Imaoka (1980), P. squamatus is a highly variable species. Moreover, most of the citations in the literature are restricted to a name without description and/or illustrations. In these circumstances, it is very difficult to establish the limit of its distribution. Parker (1964: 165) reported a capture of Psolus squamatus var. segregatus from the west coast of Mexico (ca 183-458 m depth, SW of Ensenada, off Banda Point; $31^{\circ} 38^{\prime} 20^{\prime \prime} \mathrm{N}$, $\left.116^{\circ} 51^{\prime} 24^{\prime \prime} \mathrm{W}\right)$, in the California Current area. The material was presumably identified by E. Deichmann. The same lot was later deposited at Scripps Institution of Oceanography and included by Luke (1982: 56) in his catalogue of echinoderms as Psolus squamatus. Three of the 117 specimens contained in this lot were examined during this study. Unfortunately, this material corresponded to juveniles that had been previously kept dry and ossicles could not be properly examined, thus making a positive identification impossible.

We are convinced that $P$. squamatus and $P$. squamatus segregatus are distinct species. Considering the very wide distribution range of $P$. squamatus s.l., they could even represent more than 2 species. Psolus squamatus segregatus seems to be restricted to the Pacific coast of South America. We believe that this taxonomical problem will not be solved until material preserved for DNA analysis from Japan, Canada, Central and South America, and the North Atlantic is available. Such a study is obviously beyond the scope of the present paper.

Distribution. Records in Mexico. Type locality of Psolus pauper, "Albatross" St. $3424\left(21^{\circ} 15^{\prime} \mathrm{N}, 106^{\circ} 23^{\prime} \mathrm{W}\right)$, off Tres Marías Islands, SW Gulf of California; 1237 m (676 fm), $3.3^{\circ} \mathrm{C}$ (Ludwig, 1894). H.L. Clark (1923: 161) reported on a single specimen $(\mathrm{L}=55 \mathrm{~mm})$ of Psolus squamatus, collected off California, “Albatross” St. 5695 (3333’N, $\left.120^{\circ} 17^{\prime} \mathrm{W}\right)$, in $977 \mathrm{~m}$ depth (534 fm). Probably restricted to the East Pacific, north of Central America to the Bering Sea. Present records extend the Mexican distribution of this species to SW Mexico (1840'28”N) (Fig. 2).

Psolidium Ludwig, 1887

Psolidium gracile Ludwig, 1894

Figs. 2, 3A-G, 4A-F, pl. 1A-D

Psolidium gracile Ludwig, 1893: 184 (nomen nudum).
Psolidium gracile Ludwig, 1894: 132, pl. XIII, figs. 17-19; Maluf, 1988: 88, 152; Lambert, 1996: table; Nybakken et al., 1998: 1760 .

Material examined. Six specimens $(\mathrm{L}=13-17 \mathrm{~mm}$, EMU8611; L $=16$ and $17 \mathrm{~mm}$, IG 31487/HOL 1512 RBINS/ HOL/738988), TALUD IX, St. 17. Seventeen specimens $(\mathrm{L}=12-18 \mathrm{~mm})$, TALUD XI, St. 1 (EMU-8612). Three specimens ( $\mathrm{L}=15-17 \mathrm{~mm}$ ), TALUD X, St. 3 (EMU-8624).

Small species 13-18 mm long, 6-11 $\mathrm{mm}$ wide and 5 $\mathrm{mm}$ height (pl. 1 A-C). Ventral sole more or less $70 \%$ of body length, packed with ossicles visible to naked eyes. One row of 30-35 tube feet on each side of the ventral sole (pl. 1D). Along the mid-ventral radius 1 row of a 10 of tube feet located mainly at the rear and at the front, more widely spaced out at mid-body. Dorsal tube feet very small, easily overlooked. Dorsally, very large, rounded scales up to 1 $200 \mu \mathrm{m}$ across (pl. 1C-D); 16-20 scales between mouth and anus. No valves closing mouth and anus. Dorsal scales 180-1 $200 \mu \mathrm{m}$ across, small ones 180-350 $\mu \mathrm{m}$ across and made of 1 layer (Fig. 3B), large ones half or $3 / 4$ of their surface with 1 layer and the remaining surface with 2 layers. Calcareous ring simple, without posterior processes; radial and interradial plates of the same width but radial plates nearly twice the height of the interradial (Fig. 3A). Ventral sole packed with rounded, perforated plates (3-15 holes), 125-290 $\mu \mathrm{m}$ across (Fig. 3C), surface of plates smooth, edge slightly knobbed or with blunt spines (Fig. 3C). In large specimens, ventral plates larger, more elongate, up to $450 \mu \mathrm{m}$ long, perforated by $4-19$ holes (Fig. 3D). In the ventrolateral tube feet, curved rods $120-250 \mu \mathrm{m}$ long (Fig. $3 \mathrm{~F})$, perforated plates (250-360 $\mu \mathrm{m}$ long) (Fig. 3G), and a small end-plate (170-220 $\mu \mathrm{m}$ across) (Fig. 3E). Tentacles with spiny curved rods, $200-400 \mu \mathrm{m}$ long, perforated at the extremities by 1-9 small holes (Fig. 4A); also a few perforated plates, 330-350 $\mu \mathrm{m}$ long with large holes (Fig. 4B-C). In the gonads, spiny rods, 150-300 $\mu \mathrm{m}$ long (Fig. $4 \mathrm{D}-\mathrm{F})$; spines often ending in 2-3 spinules.

\section{Remarks}

According to Maluf (1988) there are 6 species of Psolidium along the Central eastern Pacific coast. Two deep-water (P. panamense Ludwig, 1894, and P. gracile) and 4 shallow-water species (Psolidium dorsipes Ludwig, 1886; P. ekmani Deichmann, 1941; P. eubullatum Deichmann, 1941; and P. planum Deichmann, 1941). The specimens here observed fit particularly well with Psolidum gracile. Only the number of tube feet in the midventral radius and the size of the dorsal scales are different 
from the holotype. Unfortunately, the material reported by Nybakken et al. (1998) from off central California was not illustrated or described, and the species is known only from the description of the holotype. The differences observed in the TALUD specimens could be ascribed to species variability.

Distribution. No previous records in Mexico. Known from the type locality, "Albatross" St. 3392 (705'30" N, $\left.79^{\circ} 40^{\prime} \mathrm{W}\right)$, Cabo Mala, Gulf of Panama, 2323 m (1 270 fm) (Lambert, 1996), and off central California, between 2300 and $3075 \mathrm{~m}$ depth (Nybakken et al., 1998). The material collected during the TALUD survey was obtained in much shallower water $(377-920 \mathrm{~m})$ and represents the first record for the Pacific coast of Mexico (off north of Acapulco and off southern Baja California) (Fig. 2).

Dendrochirotida sp. und.

Material examined. One specimen (not measured), TALUD VIII, St. 20 (EMU-8625).

\section{Remarks}

The specimen is damaged and completely eviscerated, calcareous ring included. The presence of 5 longitudinal muscle bands and of retractor muscles of the pharynx indicate that it belongs with the Dendrochirotida. Unfortunately, the absence of ossicles in the tissues does not allow for further identification.

Order Dactylochirotida Pawson and Fell, 1965

Family Vaneyellidae Pawson and Fell, 1965

Genus Mitsukuriella Heding and Panning, 1954

Mitsukuriella unusordo sp. nov.

Figs 5A-F, 6, 7, pl. 1E-G

Material examined. Holotype $(\mathrm{L}=13.4 \mathrm{~mm})$, TALUD X, St. 9 (EMU-8629).

Small specimen $13 \mathrm{~mm}$ long, cylindrical, tapering at both ends (pl. 1E-F), $4 \mathrm{~mm}$ across at the rear, $2 \mathrm{~mm}$ across at the front and $4 \mathrm{~mm}$ across at the end. Mouth and anus terminal. Mouth surrounded by 15 digitiform tentacles ( $\mathrm{pl}$. 1G), 5 large and 10 very small, a pair of small tentacles between 2 large tentacles. Anus surrounded by 5 anal papillae. Tube feet on 1 row in each radius (pl. 1E), more crowded and longer at mid-body (pl. 1F). Dorsally, 15 tube feet on radii, and 25-30 per radius ventrally. Color in alcohol yellow-grayish. Body wall gritty to the touch, very thin, packed with large perforated plates visible to the naked eye. Calcareous ring without posterior processes; gonad present as a few undivided tubules.

In the body wall large, elongated, perforated plates, 375-850 $\mu \mathrm{m}$ long (Fig.5A-B), smaller plates smooth (Fig. 5A), larger plates partly knobbed (Fig. 5B).

Ossicles of the tube feet small perforated plates with 2-4 holes, 90-125 $\mu \mathrm{m}$ long (Fig. 5C-D). A few larger plates, $160 \mu \mathrm{m}$ long, with up to 8 holes and partly knobbed (Fig.5D). At the apex of the tube feet a small perforated end-plate (Fig. 5E) surrounded by V-shaped ossicles 100$190 \mu \mathrm{m}$ long, with a central apophysis (Fig. 5F). Ossicles of the tentacles spiny curved rods, $130-200 \mu \mathrm{m}$ long (Fig. 6), with 1 hole at each extremity, spines large, blunt.

Etymology. From the Latin "unus", "one", and "ordo", row", in reference to to the single row of tube feet in each radius.

\section{Remarks}

The presence of 15 digitate tentacles and of a calcareous ring without posterior processes are characteristic of the family Vaneyellidae as defined by Pawson and Fell (1965) and of the genus Mitsukuriella. According to Heding and Panning (1954) 2 species are known in this genus: $M$. squamulosa (Mitsukuri, 1912) from Japan, and M. inflexa (Koehler and Vaney, 1908) from India. Mitsukuriella unusordo sp. nov. is easily separated from M. squamulosa by the presence of knobs on the large perforated plates, and from $M$. inflexa by the presence of a single row of tube feet in each radius and by the shape of the large plates (elongated vs. rounded, respectively).

Distribution. Known only from the type locality (Fig. 7), Mitsukuriella unusordo sp. nov. has been collected deeper (1 205-1215 m) than the 2 other species of the genus: 250 $\mathrm{m}$ depth for M. squamulosa and $170 \mathrm{~m}$ for M. inflexa.

Family Ypsilothuriidae Heding, 1942

Genus Ypsilocucumis Panning, 1949

Ypsilocucumis californiae sp. nov.

Figs 7, 8A-F, pl. 1H

Material examined. Eight specimens from the Gulf of California. Holotype, TALUD VI, St. $26(\mathrm{~L}=15 \mathrm{~mm})$ (EMU-8613). Paratypes. Two specimens $(\mathrm{L}=12$ and 15 $\mathrm{mm})$, TALUD VIII, St. 11 (EMU-8614), 3 specimens ( $\mathrm{L}=$ 13, 14 and $21 \mathrm{~mm}$ ), TALUD VIII, St. 16 (ICML-UNAM 5.177.0), and 2 specimens ( $\mathrm{L}=13$ and $17 \mathrm{~mm})$, TALUD $X$, St. 3 (IG 31487/HOL 1514 RBINS/HOL/738995).

Specimens spherical, with 2 dorsal tubes (1 oral and 1 anal) contracted and well separated from each other (pl. 1H). Length of specimens (tubes not included) from 
13 to $21 \mathrm{~mm}$. Distance between mouth and anus from 7 to $12 \mathrm{~mm}$. Body wall bristle, thin, translucent and gritty to the touch, packed with large scales (visible to naked eye) with spires protruding outside. Tube feet very small, difficult to observe, apparently only present along the radius. Calcareous ring brittle, very thin, with radial and interradial plates of the same size and without posterior process (Fig. 8A); anterior process of radial plates with a deep groove for the insertion of the retractor muscles of the introvert.

All specimens contracted, with the introvert inside. After dissection 2 very long (at least $2 \mathrm{~mm}$ long when contracted) digitiform tentacles observed. Other tentacles minute, not counted. Retractor muscles of introvert very thin, attached to the body wall at mid-body length. Gonad present, reduced to a few, short, divided tubules, some containing very large oocytes.

Body wall with large scales, developing from small, single layered perforated plates, 200-700 $\mu \mathrm{m}$ across, without pillar (Fig. 8B), to 2-layered perforated scales (edge of the scale very often single layered) with an eccentric spire (Fig. 8C). Scales are 700 to $1000 \mu \mathrm{m}$ across, their spire, made of the fusion of several spiny pillars, 350-400 $\mu \mathrm{m}$ high (Fig. 8D). In the long digitiform tentacles curved rods, $150-370 \mu \mathrm{m}$ long, with lateral blunt spines and enlarged perforated extremities (Fig. 8E), most rods very thin $( \pm 10 \mu \mathrm{m}$ across $)$, a few thicker $(20-25 \mu \mathrm{m}$ across) (Fig. 8 F).

\section{Remarks}

The specimens at hand fit well with the diagnosis of the family Ypsilothuriidae. The presence of multilayered scales, the eccentric position of the spire of the scales, and the retractile oral and anal cones clearly indicate that the new species belongs to the genus Ypsilocucumis (see Panning, 1949) which included 3 species: Ypsilocucumis asperrima Théel, 1886, Y. turricata (Vaney, 1906), and Y. scotiae (Vaney, 1906). The latter 2 species, erected by Vaney (1906b), have since been moved by O'Loughlin (2002) and O'Loughlin et al. (2009) to the genera Paracucumis Mortensen, 1925 and Crucella Gutt, 1990, respectively. Ypsilocucumis californiae sp. nov. differs from $Y$. asperrima in the size of the scales (700-1 $000 \mu \mathrm{m}$ vs. $>2000 \mu \mathrm{m}$, respectively), in the number of layers of the scales (maximum 2 vs. several, respectively) and in its zoogeographic distribution (Pacific coast of North America vs. Caribbean Sea, respectively). According to Théel (1886) and Deichmann (1930, 1954) small specimens of $Y$. asperrima (length of body, oral and anal cones not included, $<15 \mathrm{~mm}$ ) have many singlelayered scales. Ypsilocucumis californiae sp. nov. presents the same characteristics. The rods of the tentacles are identical to those of Ypsilothuria bitentaculata attenuata E. Perrier, 1886 (see Massin 1996: Fig. 2A).

Etymology. The species is a noun in the genitive, referring to the geographic area (Gulf of "California") of collection. Distribution. Central and southern Gulf of California, Mexico (Fig. 7).

Ypsilothuria bitentaculata (Ludwig, 1893)

Fig. 7

Sphaeroturia bitentaculata Ludwig, 1893: 184; 1894: 141, pl. XII, figs. 16-17, pl. XIV, figs. 5-14; H.L. Clark, 1913: 229; Ohshima, 1915: 266; Ludwig and Heding, 1935: 76, textfigs. 55-57 (list of citations and synonymy); Parker, 1964: 165; Hansen, 1975: 216; Luke, 1982: 56.

Ypsilothuria bitentaculata; R. Perrier, 1902: 517; Koehler and Vaney, 1905: 87; Panning, 1949: 455; Madsen, 1955: 167; Caso, 1961: 371; Thandar, 1984: 226, Fig. 39a-k (list of citations and synonymy); Maluf, 1988: 95, 156; Nybakken et al. 1998: 1759, 1778; Maluf, 1991: 358; Lane et al., 2000: 491; Maluf and Brusca, 2005: 342; Tilot, 2006: 59; Sastry, 2007: 254.

Material examined. One specimen $(\mathrm{L}=12 \mathrm{~mm})$, TALUD XII, St. 5 (EMU-8615).

\section{Remarks}

Ypsilothuria bitentaculata is considered a cosmopolitan species, collected in the East and West Pacific Ocean, Indian Ocean, North Atlantic Ocean and Mediterranean Sea. Two varieties have been recognized by Heding (1942): Y. b. attenuata E. Perrier, 1886 and Y. b. virginiensis Heding, 1942. The latter is only known from the North Atlantic Ocean, whereas the former is cosmopolitan. Due to the complexity in separating the varieties or subspecies of $Y$. bitentaculata and the lack of reliable information related to their distribution, we have considered the Mexican material as belonging to Sphaerothuria bitentaculata sensu Ludwig (1893, 1894).

Distribution. Records in Mexico. "Albatross” St. 3424 $\left(21^{\circ} 15^{\prime} \mathrm{N}, 106^{\circ} 23^{\prime} \mathrm{W}\right), 1237 \mathrm{~m}$ (676 fm) (Ludwig, 1894). "Albatross" St. 5675, SW of San Cristobal Bay

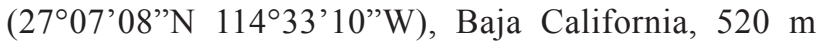
(284 fm) (Parker, 1963). Off Salina Cruz (14²8'30"N, 9309'30"W), 3 539-3 610 m (Parker, 1964; Luke, 1982). 
Off Tres Marias Islands (probably “Albatross" St. 3424) (Maluf and Brusca, 2005). Syntypes were collected at different stations of the "Albatross", roughly between $00^{\circ} 54^{\prime} \mathrm{N}$ and $21^{\circ} 15^{\prime} \mathrm{N}$ (Ludwig, 1894). From central California (Nybakken et al. 1998), where it is the most abundant species, San Cristobal Bay, Baja California, Mexico, to San Francisco Cape, Equator; Indo-West Pacific (Maluf and Brusca, 2005). Widely distributed along the Pacific coast of Mexico (Fig. 7).

Order Elasipodida Théel, 1882

Family Laetmogonidae Ekman, 1926

Genus Pannychia Théel,1882

Pannychia moseleyi Théel, 1882

Fig. 9

Pannychia moseleyi Théel, 1882: 3, 88, pl. XVII, figs. 1-2, pl. XXXII, figs. 1-13; Hansen, 1975: 72, fig. 26 (synonyms and citations); Maluf, 1988: 101, 161 (synonyms and citations); Solís-Marín et al., 1997: 256; Nybakken et al., 1998: 1778; Pawson and Ahearn, 2001: 42; Solís-Marín et al., 2005: 132; Tilot, 2006: 42, 43, fig. 75, 60; Anonymous, 2004: 4, 1 pl.; Pawson, 2009: 398; Solís-Marín et al., 2009: 144, pl. 47. figs. A-H.

Material examined. Two specimens $(\mathrm{L}=180 \mathrm{~mm}$, EMU-8632; L = 182 mm, IG 31487/HOL 1509 RBINS/ HOL/738972), TALUD VIII, St. 3. One specimen ( $\mathrm{L}=11$ $\mathrm{mm})$, TALUD VIII, St. 11 (EMU-8617). One specimen $(\mathrm{L}=$ $85 \mathrm{~mm}$ ), TALUD IX, St. 10 (EMU-8616). Four specimens (L = 41-89 mm; EMU-8631; L = 79 mm, IG 31487/HOL $1516 \mathrm{RBINS} / \mathrm{HOL} / 739010)$ and 3 specimens $(\mathrm{L}=40$ and $80 \mathrm{~mm}$, EMU-8619; L = $61 \mathrm{~mm}$, IG 31487/HOL 1510 RBINS/HOL/738978), TALUD XII, St. 25. One specimen (L=104 mm), TALUD XII, St. 29 (EMU-8618).

The 12 specimens examined are 40-182 $\mathrm{mm}$ long and 6-34 mm across. The body wall contains a few characteristic wheels, $120-235 \mu \mathrm{m}$ across, with 11-15 spokes.

\section{Remarks}

As noticed by Hansen (1975), the number and size of wheels are highly variable and not related to the size of the specimens. The observed wheels are similar to the ones described and figured by Hansen (1975) from a Challenger's specimen from the Gulf of Panama.

Distribution. Records in Mexico. "Albatross" St. 3431 $\left(23^{\circ} 59^{\prime} \mathrm{N}, 108^{\circ} 40^{\prime} \mathrm{W}\right), 1748 \mathrm{~m}$ (955 fm); St. 3432 (242'30”N, 10903'20”W), 2600 m (1 $421 \mathrm{fm})$; St. 3436 $\left(27^{\circ} 34^{\prime} \mathrm{N}, 110^{\circ} 53^{\prime} 40^{\prime \prime} \mathrm{W}\right), 1656 \mathrm{~m}(905 \mathrm{fm}) ; 2.9-3.9^{\circ} \mathrm{C}$
(Ludwig, 1894). "Albatross" St. 5676, off San Juanico (2531'15”N, 113'29'30”), 1165 m (647 fm); St. 5685, SW of Ballenas Bay $\left(25^{\circ} 42^{\prime} 45^{\prime \prime} \mathrm{N}, 113^{\circ} 38^{\prime} 30^{\prime \prime}\right), 1$ 180m $(645 \mathrm{fm}) ; 3.8^{\circ} \mathrm{C}\left(39^{\circ} \mathrm{F}\right)$ (H.L. Clark, 1913). "Albatross" St. 3418 (16³'N, 9952'30”'W), 1208 m (660 fm); St. 3425

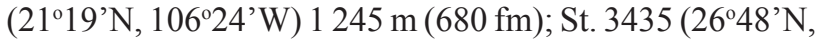
$\left.110^{\circ} 45^{\prime} 20^{\prime \prime} \mathrm{W}\right) 1572 \mathrm{~m}$ (859 fm); St. $3436\left(27^{\circ} 34^{\prime} \mathrm{N}\right.$, $110^{\circ} 53^{\prime} 40$ ”'W), $1656 \mathrm{~m}$ (905 fm); 2.9-3.2 C (Ludwig, 1894; as Laetmophasma fecundum) (Fig. 9). The record of Luke (1982: 58), at $32^{\circ} 24^{\prime} 42^{\prime \prime} \mathrm{N}-117^{\circ} 27^{\prime} 45^{\prime \prime} \mathrm{W}$, is at the southern limit of the Mexican-USA border (1 204-1 226 m, San Diego Trough). Solís-Marín et al. (1997) cited this species

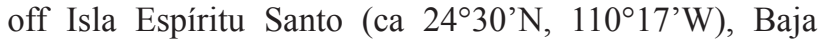
California, Mexico, and Solís-Marín et al. (2005) include 2 records for the Gulf of California, both corresponding to material collected by the "Albatross" (Solís-Marín, pers. comm.). Two additional records are provided by SolísMarín et al. (2009) for the Gulf of California $\left(25^{\circ} 43^{\prime} 50^{\prime \prime} \mathrm{N}\right.$, $\left.109^{\circ} 53^{\prime} 59^{\prime} \mathrm{W}\right)$ and the California Current area $\left(28^{\circ} 03^{\prime} \mathrm{N}\right.$, $1115^{\circ} 10^{\prime} \mathrm{W}$ ) (Fig. 9). Syntypes are from "Challenger" Sts. 164 and $169,34^{\circ} 8^{\prime} \mathrm{S}, 152^{\circ} \mathrm{E}$, and $37^{\circ} 34^{\prime} \mathrm{S}, 1^{\circ} 9^{\circ} 22^{\prime} \mathrm{E}, \mathrm{E}$ of New Zealand, in depths of 1 281-1 739 m (700-950 fm); $2.2-4.2^{\circ} \mathrm{C}$ (Théel, 1882). Widely distributed throughout the East Pacific, Pannychia moseleyi has been reported from off Central California (Nybakken et al. 1998) and San Diego (Luke, 1982) to ca $6^{\circ} \mathrm{S}$, off northern Peru, with many intermediate localities (Maluf, 1988: 101). It also occurs off Hawaii and in the SW Pacific, and features a very wide Indo-Pacific distribution (Hansen, 1975; Maluf, 1988; Thandar, 2008). It ranges from 212 to $2599 \mathrm{~m}$ depth, and the TALUD material was collected within that depth range (920-1 $879 \mathrm{~m}$ ). Information based on deep-water trawls and photographs taken in the Gulf of California and off the coast of California (Solís-Marín et al., 1997; Anonymous, 2004; Nybakken, 2010) and off CaliforniaOregon-Washington (Keller et al., 2007) indicates that $P$. moseleyi is an abundant species in these areas. According to Tilot (2006: fig. 75) this species is present (photographic evidence) in the Clipperton-Clarion fractures zone.

Genus Laetmogone Théel, 1879

Laetmogone scotoeides (H.L. Clark, 1913)

Figs 9, 10, A-E

Laetmenoceus scotoeides H.L. Clark, 1913:231.

Laetmogone scotoeides Hansen, 1975: 61, Fig. 23; Maluf, 1988: 100, 160; Thandar, 1998: 87.

Material examined. One specimen ( $\mathrm{L}=90)$, TALUD XII, St 9 (EMU-820). One specimen $(\mathrm{L}=150 \mathrm{~mm})$, TALUD XII, St. 10 (EMU-8634).

Additional material examined. One specimen $(\mathrm{L}=86 \mathrm{~mm})$ 
of Laetmogone wyvillethomsoni, Cruise MV69-VI-9-W, Patton Escarpment, off Baja California, Mexico (31 ${ }^{\circ} 11^{\prime} \mathrm{N}$, 119³6’W), 18/December/1969, 3600-3676 m depth (SIO-E 8) (coll. C. Hubbs, S. Luke).

The $90 \mathrm{~mm}$ long specimen is in poor condition and does not allow for an anatomical description. The $150 \mathrm{~mm}$ long specimen is dark violet. On each side of the ventral sole, a single row of approximately 20 very large tube feet. Mouth ventral, surrounded by 15 tentacles; anus terminal. In the body wall numerous wheels. Small wheels 55-130 $\mu \mathrm{m}$ in diameter with 13 spokes and 4 central rays. Large wheels $120-280 \mu \mathrm{m}$ in diameter with $8-12$ spokes and 5 central rays (fig $10 \mathrm{~A}$ ). No clear-cut distinction between large and small wheels. Tube feet with spiny rods (190-420 $\mu \mathrm{m}$ long) (Fig. 10D), wheels, and an end-plate. Wheels similar to those of the body wall, small wheels 30-100 $\mu \mathrm{m}$ in diameter (Fig. 10B), large wheels $120-290 \mu \mathrm{m}$ in diameter (Fig. 10C). The end-plate is composed of several spiny, irregularly ramified rods (fig 10E).

\section{Remarks}

According to Hansen (1975), the number of tentacles (15), the size of the large wheels (up to $300 \mu \mathrm{m}$ ) with 5 central rays are typical of Laetmogone scotoeides. The size of the large wheels is particularly striking: $50 \%$ to $100 \%$ larger than in any other Laetmogone species. (Hansen, 1975; Thandar, 1998). The specimen in poor condition ( $\mathrm{L}=150 \mathrm{~mm}$ ) was first identified as a $L$. wyvillethomsoni. However, examination of the wheel diameter of a specimen of $L$. wyvillethomsoni collected off northern Baja California and obtained on loan (see additional material examined) shows that this poorly preserved specimen also belongs to $L$. scotoeides.

Distribution. Record in Mexico. Type locality, "Albatross" St. 5685, SW of Ballenas Bay (2542'45”N, 113³8’30”W), west coast of Baja California, $1180 \mathrm{~m}(645 \mathrm{fm})$ (H.L. Clark, 1913). Now from off Petatlán, Guerrero (17¹1'18'N, 101²8'30W), SW Mexico (Fig. 9). According to Maluf (1988) L. scotoeides had been reported only from the type locality. The record for the Bay of $\mathrm{La} \mathrm{Paz} \mathrm{(east} \mathrm{coast} \mathrm{of}$ the southern Baja California Peninsula), Mexico, in SolísMarín et al. (1997: 255) is an error (Solís-Marín, pers. comm.). It is not cited by Solís-Marín et al. (2005) and Honey-Escandón et al. (2008) for Pacific Mexico and we therefore conclude that no additional record is available for this species. Present records off SW Mexico occur in a depth range of $1180-1420 \mathrm{~m}$, very similar to the type locality $(1173 \mathrm{~m})$ and are new for the Pacific coast of Mexico. It confirms the restricted distribution of $L$. scotoeides which seems to be endemic of Pacific Mexico. This is in contrast with the other Laetmogone species which generally have a wide distribution (Hansen, 1975).

Family Psychropotidae Théel, 1882

Genus Benthodytes Théel, 1882

Benthodytes cf. sanguinolenta Théel, 1882

Fig. 9

Benthodytes sanguinolenta Théel, 1882: 3-4, 104, pl. XXIII, pl. XL, figs. 4-5, pl. XLII, fig. 6; Ludwig, 1894: 53, pl. I, figs. 1-8; H.L. Clark, 1913: 233; 1920: 142; 1923: 162; Hansen, 1975: 94, pls. III-VI, pl. IX, figs. 6-7, pl. XII, figs. 4-5, fig. 116 (list of citations); Parker, 1964: 165; Luke, 1982: 58; Maluf, 1988: 101, 161; Nybakken et al. 1998: 1778; Maluf, 1991: 360; Honey-Escandón et al., 2008: 58.

Material examined. One specimen $(\mathrm{L}=120 \mathrm{~mm})$, Talud XII, St 15 (EMU-8627).

Specimen flattened, with mouth ventral and anus dorsal. Skin slightly damaged. Unpaired dorsal appendage absent. Circum-oral papillae present. Mid-ventral tube feet present, well developed. Color in alcohol grey-white, with patches of purple. Tentacles purple. No ossicle in body wall and tube feet.

\section{Remarks}

According to Hansen (1975) the general aspect of the specimen examined herein fits well with the genus Benthodytes. Because of the absence of ossicles and the size and position of the ventral tube feet (see Ludwig, 1894: pl. I, fig. 1), the specimen examined is most probably $B$. sanguinolenta but some doubt remains, and it was labeled $B$. cf. sanguinolenta.

Distribution. Records in Mexico. "Albatross" St. 3415 (1446’ N, 9840’W), $3383 \mathrm{~m}$ (1 $879 \mathrm{fm}) ; 2.2^{\circ} \mathrm{C}$ (Ludwig, 1894). Off San Tomas Point, SW of Magdalena Bay, and off Rosario Bay; 1 969-3 221 m (1 076-1 760 fm); 2.83$3.30^{\circ} \mathrm{C}$ (37.1-38.1 $\left.{ }^{\circ} \mathrm{F}\right)$ (H.L. Clark, 1913). "Albatross" station $4732\left(16^{\circ} 32^{\prime} 30^{\prime}\right.$ 'N , 119 $\left.59^{\circ} \mathrm{W}\right) ; 3682 \mathrm{~m}$ (2 $\left.012 \mathrm{fm}\right)$; $1.5^{\circ} \mathrm{C}\left(34.8^{\circ} \mathrm{F}\right)$ (H.L. Clark, 1920). Undetermined stations of the "Albatross", off Baja California, in depths exceeding $1000 \mathrm{fm}$ (H.L. Clark, 1923). W of Punta Banda (31 ${ }^{\circ} 18^{\prime} \mathrm{N}$, $\left.117^{\circ} 36^{\prime} \mathrm{W}\right)$, Patton Escarpment (30 $\left.52^{\prime} \mathrm{N}, 116^{\circ} 53^{\prime} \mathrm{W}\right)$, and

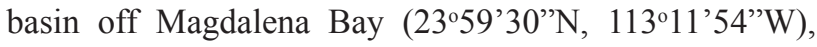
Baja California, Mexico; 1 975-3 518 m depth (Parker, 1964; Luke, 1982). Off western Baja California (2940'12”N, 117 06'36”W); 2 708-2 763 m (Parker, 1964). Environmental data of the material cited by Parker (1964): $2.0-2.5^{\circ} \mathrm{C}$ and 1.3-2.8 $\mathrm{ml} \mathrm{O}_{2} / 1$. Honey-Escandón et 
al. (2008) reported this species for the California Current area, in 2 localities off Baja California (W of San José Point, 31'23'45"N, 118³1'30'W; SW of San Carlos Point, $\left.29^{\circ} 29^{\prime} \mathrm{N}, 116^{\circ} 18^{\prime} \mathrm{W}\right)$ (Solís-Marín, pers. comm.) (Fig. 9). Syntypes are from off Chile $\left(34^{\circ} 7 \mathrm{~S}, 73^{\circ} 56^{\prime} \mathrm{W}\right.$, and $38^{\circ} 7^{\prime} \mathrm{S}$, $\left.94^{\circ} 4^{\prime} \mathrm{W}\right)$, in depths of 2 745-4 $072 \mathrm{~m}$ (1 500-2 $\left.225 \mathrm{fm}\right)$; $1.3-1.4^{\circ} \mathrm{C}$ (Théel, 1882). Throughout almost the entire Indo-Pacific, from 768 to $7250 \mathrm{~m}$ depth, mostly in depths $>2000 \mathrm{~m}$ (Hansen, 1975). Central California and the Channel Islands, California, USA, to Chile (Maluf, 1988; Nybakken et al., 1998).

Unidentified Elasipodida

Material examined. One specimen $(\mathrm{L}=95 \mathrm{~mm})$, TALUD VIII, St. 22 (EMU-8626). One specimen ( $\mathrm{L}=115 \mathrm{~mm}$ ), TALUD XII, St. 8. (EMU-8623). One specimen $(\mathrm{L}=152$ mm), TALUD XIII, St. B (EMU-8628).

\section{Remarks}

The 3 specimens examined look like Elasipodida because of their general shape and color pattern (dark violet). The body wall of each specimen, however, is damaged making it very difficult to ascertain the number and position of the tube feet and the presence/absence of a brim. Moreover, ossicles are completely lacking.

Order Aspidochirotida Grube, 1840

Family Synallactidae Ludwig, 1894

Genus Synallactes Ludwig, 1893

Synallactes alexandri Ludwig, 1893

Figs. 11A-H, 12

Synallactes alexandri Ludwig, 1893: 178; Hansen, 1975: 215; Maluf, 1988: 99, 160; Maluf, 1991: 360; Solís-Marín 2003: 249, figs. 194-200.

Scotodeima alexandri; Ludwig, 1894: 21, pl. IX, figs. 10-19.

Bathyplotes hancocki; Domantay, 1953:136 (nomen nudum); 1961: 333 (nomen nudum).

Bathyplotes macullochae; Domantay, 1953: 136 (nomen nudum); 1961: 333 (nomen nudum).

Bathyplotes hancocki Domantay, 1961: 334.

Bathyplotes maccullochae Domantay, 1961: 335.

Material examined. Six specimens $(\mathrm{L}=46-97 \mathrm{~mm}$, EMU-8633; L = $81 \mathrm{~mm}$, IG 31487/HOL 1515 RBINS/ HOL/739007), TALUD VIII, St. 11.

Six specimens examined, 46-97 $\mathrm{mm}$ long and 4-12 mm across. Disposition of mouth, anus, ventral tube feet and dorsal papillae as described by Ludwig (1894), with the rows of dorsal papillae less visible than in the type material. 18-20 small peltate tentacles. No ossicles in the ventral body wall; a few, gathered in heaps, in the dorsal body wall. In the dorsal body wall and dorsal papillae only cross-shaped ossicles with 3-4 arms and 1 central pillar (Fig. 11A-B); each arm forked or perforated at the extremity. Cross-shaped ossicles $80-100 \mu \mathrm{m}$ across in the body wall (Fig. 11A), and $100-115 \mu \mathrm{m}$ across in the dorsal papillae (Fig. 11B). In the tube feet very numerous, spiny, slightly curved rods, 300$700 \mu \mathrm{m}$ long (Fig. 11C), a 1 piece end-plate, 550-650 $\mu \mathrm{m}$ across, and cross-shaped ossicles similar to those in the body wall (Fig. 11D), some transformed in table with 4-5 large perforations (Fig. 11E). Central pillar of cross-shaped ossicles ending in a few spines, its height never exceeding cross diameter. Tentacles with numerous spiny rods, straight to strongly curved, $40-700 \mu \mathrm{m}$ long (Fig. 11F-H), longer rods (Fig. 11H) located at the base of the tentacles.

\section{Remarks}

The specimens examined are much smaller than in the types series (46-97 $\mathrm{mm}$ vs. $145-175 \mathrm{~mm}$ ) but the ossicles are very similar. According to Maluf (1988) 4 species of Synallactes have been reported in the Central eastern Pacific, all from water deeper than $350 \mathrm{~m}$, between SW Mexico and northern Peru. The only previous record of the genus for Pacific Mexico is for Synallactes ishikawai f. ind. (= S. sagamiensis Augustin, 1908), reported from the Gulf of Tehuantepec, SW Mexico, by Parker (1964). Whether this identification (presumably by E. Deichmann) was correct or not is impossible to determine. Haney (2004) reports S. alexandri from off California, but a close examination of the illustrations included in this contribution indicates that her material most probably belongs to a new species recently described: Synallactes virgulosolida Massin and Hendrickx, 2010. Nybakken et al. (1998) reported S. aenigma from central California, with no illustrations, but this species is clearly distinct from $S$. alexandri.

Solís-Marín (2003) re-examined material and descriptions of Synallactes worldwide and retained 22 valid species. He synonymized both Bathyplotes hancocki and $B$. maccullochae with Synallactes alexandri, thus extending the distribution of the latter to southern California. The record of $B$. hancocki for the Gulf of California, cited by Domantay (1961), however, is in error. All specimens examined by this author (9 specimens from 5 stations) and presently in the echinoderms collection at the Los 
Angeles County Museum of Natural History (except the holotype from off San Clemente Island, California, which is apparently missing), were collected off Santa Catalina Islands, California (G. Hendler, pers. comm.). The material examined herein, however, extends the distribution of $S$. alexandri to the Gulf of California.

Distribution. The species is new to Mexico. The syntypes are from "Albatross" Sts. 3354, off Mariato Point, Panama $\left(07^{\circ} 45^{\prime} \mathrm{N}, 80^{\circ} 50^{\prime} \mathrm{W}\right)$, and 3406 , off the Galapagos Islands $\left(00^{\circ} 16^{\prime} \mathrm{S}, 90^{\circ} 21^{\prime} 30^{\prime \prime} \mathrm{W}\right)$ (Ludwig, 1894). Off Santa Barbara, California, in depths of 278-550 m (152-300 fm) (Domantay, 1961, as B. hancocki and B. maccullochae; Solís-Marín, 2003). In depths of 585-1 018 m (Hansen, 1975; Maluf, 1988; Maluf, 1991). Present record extends the distribution range of $S$. alexandri within the southwestern Gulf of California (Fig. 12) and fills the distribution gap between Panama and California.

Synallactes virgulasolida Massin and Hendrickx, 2010 Synallactes virgulasolida Massin and Hendrickx, 2010: 600, figs. 1-3.

Material examined. Three specimens $(\mathrm{L}=50-85 \mathrm{~mm})$, TALUD VIII, St. 16 (EMU-8608; IG.31487-HOL 1506; ICML-UNAM 5.171.0).

\section{Remarks}

This species has been recently described in a separate paper (Massin and Hendrickx, 2010).

Distribution. Known only from the SW Gulf of California (Fig. 12), Mexico, at $1030 \mathrm{~m}$ depth.

Order Molpadiida Haeckel, 1896

Family Molpadiidae J. Müller, 1850

Genus Molpadia Risso, 1826

Molpadia intermedia (Ludwig, 1894)

Figs 13, 14

Trochostoma intermedium Ludwig, 1893: 185 (nomen nudum).

Trochostoma intermedium Ludwig, 1894: 161, pl. XVI, figs. 7-21.

Molpadia intermedia; H.L. Clark, 1907: 162, pl. 12, figs. 5-15; 1913: 228; Deichmann, 1937: 174; Caso, 1961: 375; Maluf, 1988: 105, 163; Nybakken et al. 1998: 1778; Maluf and Brusca, 2005: 343; Solís-Marín et al., 2005: 132; Tilot, 2006: 62; Honey-Escandón et al., 2008: 58; Solís-Marín et al., 2009: 148, pl. 49.

Haplodactyla intermedia; Heding, 1931: 280.
Material examined. One specimen $(\mathrm{L}=92 \mathrm{~mm})$, TALUD VI, St. 25 (EMU-8621).

Body very similar to M. musculus, with a short tail ( $\pm 10 \%$ of body length). No ossicles in body wall but numerous phosphatic deposits. Ossicles of the tail tables only, no fusiform rods. Most of the tables are very irregular and broken. The disc is $130-210 \mu \mathrm{m}$ across, perforated by 3-5 large holes (Fig. 13). Spire made of 2-3 pillars, 100$120 \mu \mathrm{m}$ high, fused at the top.

\section{Remarks}

Molpadia intermedia is said to have a long tail (20$25 \%$ of total body length; Ludwig, 1894; H.L. Clark, 1907; Solís-Marín et al., 2009). The tail of the observed specimen is very short ( $10 \%$ of body length), making it close to $M$. musculus. The absence of fusiform rods and the presence of irregular tables in the tail, however, are characteristic of M. intermedia (see Ludwig, 1894: pl. XVI, figs. 16-19). Molpadia intermedia is the most common species of the genus along the Central eastern Pacific coast (H.L. Clark, 1907; Deichmann, 1937) and it is therefore surprising that only 1 specimen was collected during the TALUD survey. Distribution. Records in Mexico. "Albatross" Sts. 2838 $\left(28^{\circ} 12^{\prime} \mathrm{N}, 115^{\circ} 09^{\prime} \mathrm{W}\right), 79 \mathrm{~m}$ depth, and $3431\left(23^{\circ} 59^{\prime} \mathrm{N}\right.$, $\left.108^{\circ} 40^{\prime} \mathrm{W}\right), 1791 \mathrm{~m}$ depth (H.L. Clark, 1907); "Albatross"

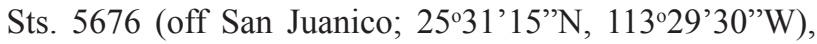
5683 (off Cabo San Lucas; 22 46'45”N, 109'50'15”W),

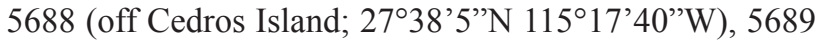
and 5690 (off Ballenas and Rosario Bay; 29 $23^{\prime} 00 \mathrm{~N}$ $116^{\circ} 14^{\prime} \mathrm{W}$ and $\left.29^{\circ} 29^{\prime} \mathrm{N} 116^{\circ} 18^{\prime} \mathrm{W}\right)$, Baja California, in depths of $961-2015 \mathrm{~m}(525-1101 \mathrm{fm}) ; 3.30-4.38^{\circ} \mathrm{C}$ (38.1-39.9 $\mathrm{F})$ (H.L. Clark, 1913). East of Cedros Island (St 126-DA, Templeton Crocker), Baja California (Deichmann, 1937). Solís-Marín et al. (2005) reported 2 records for the Gulf of California and Honey-Escandón et al. (2008) 2 records for the California Current area. These records are probably the same as those cited by SolísMarín et al. (2009; 5 records in total), and were included in this compilation $\left(28^{\circ} 12^{\prime} 00^{\prime \prime} \mathrm{N}, 115^{\circ} 09^{\prime} 09^{\prime \prime} \mathrm{W}\right.$; $24^{\circ} 15^{\prime} 18^{\prime \prime}$

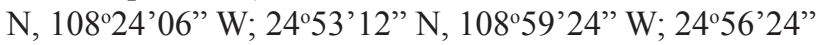
N, 10905'36” W; 2451'41” N, 10857'52” W) (Fig. 14). From Alaska to Cabo Mala, Panama; West Pacific (Maluf and Brusca, 2005); in depths of 55-2 014 m (Maluf, 1988).

\section{Molpadia musculus Risso, 1826}

Fig. 14

Molpadia musculus Risso, 1826: 293; H.L. Clark, 1907: 35, 158, 165, pl. XI; 1913: 228; 1923: 161; Caso 1961: 
375; Pawson, 1977: 100, figs. 3a-d, map 1 (synonymy and list of citations); Luke, 1982: 59; Maluf, 1988: 105, 163; Nybakken et al., 1998: 1778; Maluf and Brusca, 2005: 343; Solís et al., 2005: 132; Honey-Escandón et al., 2008: 58; Solís-Marín et al., 2009: 150, pl. 50.

Molpadia musculus forma violacea; Parker 1964: 165.

Molpadia musculus forma spinosa; Parker, 1964: 165.

Material examined. Four specimens $(\mathrm{L}=17$ and $47 \mathrm{~mm}$, EMU-4203; L $=52$ and $58 \mathrm{~mm}$, IG 31487/HOL 1513 RBINS/HOL/738993), TALUD III, St. 14B. One specimen ( $\mathrm{L}=98 \mathrm{~mm}$ ), TALUD IX, St. 16 (EMU-8622).

No ossicles in the body wall, but only numerous phosphatic deposits. In the tail fusiform rods only. The smaller the specimen, the more numerous the ossicles.

\section{Remarks}

Rods in the tail show the same diversity as the one reported and illustrated by Pawson (1977: fig. 2a-f) for M. musculus from off southern Chile and South Shetland Island. Molpadia musculus is considered a cosmopolitan and highly variable species, described repeatedly under different names or varieties (see Maluf, 1988). A detailed review of species of Molpadia occurring in the southern oceans is available in Pawson (1977), including the redescription of M. musculus. Records for Molpadia musculus forma musculus and for Molpadia musculus forma spinosa by Parker (1964: 165) are for southern California and northern Guatemala, respectively, in both cases close to the border limit with Mexico.

Distribution. Records in Mexico. "Albatross" Sts. 3418,

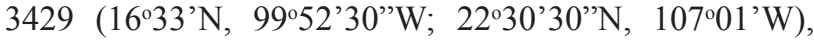
1 188-1 654 m (H.L. Clark, 1907). SW of Magdalena Bay (“Albatross" St. 5684; 2323’30”N, 112 $30^{\circ} \mathrm{W}$ ) and off Santo Tomas Point (“Albatross" St. 5692, 31'23'45”N, 118031'30”W), 1 969-3 170 m (1 076-1 760 fm); 2.83 $\left(37.1^{\circ} \mathrm{F}\right)$ (H.L.Clark, 1913, 1923). "Albatross" St. 3434 (2529’30”N, 10948’W), 2906 m (1 588 fm) (Ludwig, 1894; as Trochostoma violaceum). "Albatross" St. 3436 $\left(27^{\circ} 34^{\prime} \mathrm{N}, 110^{\circ} 53^{\prime} 40^{\prime} \mathrm{W}\right), 1656 \mathrm{~m}$ (905 fm); $2.9^{\circ} \mathrm{C}$ (Ludwig, 1894; as Ankyroderma spinosum). Off Salina

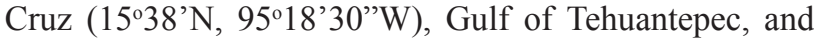
NW of San Juanico Island (22 $\left.11^{\prime} 12^{\prime \prime} \mathrm{N}, 107^{\circ} 46^{\prime} 06^{\prime \prime} \mathrm{W}\right)$, Gulf of California, in depths of $1006-3001 \mathrm{~m} ; 2.0-8.0^{\circ} \mathrm{C}$ and 0.1-2.0 $\mathrm{ml} \mathrm{O}_{2} / 1$ (Parker, 1964). Solís-Marín et al. (2005) reported 1 record for the Gulf of California, off Mazatlán (22 $\left.30^{\prime} 30^{\prime} \mathrm{N}, 107^{\circ} 01^{\prime} \mathrm{W}\right)$, and Honey-Escandón et al. (2008) 1 record over the Lusitania Bank (2323'30'N, $\left.112^{\circ} 00^{\prime} 30^{\prime} \mathrm{W}\right)$, off Baja California Sur, in the California
Current area (Solís-Marín pers. comm.). Solís-Marín et al. (2009) reported an additional lot in the holdings of the Smithsonian Institution, from off Mazatlán $\left(23^{\circ} 12^{\prime} \mathrm{N}\right.$, $106^{\circ} 25^{\prime} \mathrm{W}$ ) (Fig. 14). The type locality is the Gulf of Nice, Mediterranean Sea. Widely distributed in the East Pacific, it is known from Monterey, California, to southern Chile. A cosmopolitan species also recorded worldwide except north of the Arctic Circle (Pawson, 1977; Maluf, 1988; Borrero-Peréz et al., 2005).

The depth range provided by Maluf (1988) for this species (4 to $5205 \mathrm{~m}$ depth) is astonishing. A search in the literature indicates that the sample presumably collected at only $4 \mathrm{~m}$ depth most certainly corresponds to a record by Parker (1964) at a locality situated in the Bay of La Paz (St. 4, depth 4-7 $\mathrm{m}$, water temperature $22^{\circ} \mathrm{C}$ ), sampled in 1959. The extremely high water temperature and the subtidal character of the sampling site indicate that this record is uncertain. Perhaps this sample had been confused with the preceding sample (St. 3, visited 2 days earlier, same area, $2710 \mathrm{~m}$ depth) and erroneously labeled. Depth records for Pacific Mexico are from 830 to $3170 \mathrm{~m}$. According to Pawson (1977), however, M. musculus has been collected from 35 to $5205 \mathrm{~m}$, still a remarkably wide bathymetric range.

\section{Discussion}

It should be emphasized that in most surveys either survey methods, sampling effort, or depth range are distinct, thus rendering formal comparison difficult. Depth range, for example, is very important for the distribution of the Elasipodida, particularly for the families Psychropotidae and Elpidiidae (Hansen, 1975; Gebruk, 1990). Most of the species belonging to those families live deeper than 2000 $\mathrm{m}$. Consequently, Elasipodida collected at a depth range of 350-2 $200 \mathrm{~m}$ (present study) or 400-2 $900 \mathrm{~m}$ (Gage et al., 1985) represent $31 \%$ and $27 \%$ of the species diversity, respectively. If the sampled depth is $2000-4000$ (Sibuet, 1977) or 350-4 000 (Ludwig, 1894) the Elasipodida species diversity can reach up to $37 \%$ and $45 \%$, respectively.

As a result of the compilation of the data available in the literature, and including the 13 species collected during the TALUD cruises, 31 deep-water species (29 identified at species level and 2 at genus level) have at least 1 record from off the Pacific coast of Mexico: 13 in the California Current area (CC, south of the USA border), 20 in the Gulf of California (GC), and 14 (15 if the doubtful record of Peniagone intermedia is considered) along southwestern Mexico (SWM, south of Banderas Bay to the Guatemala border). Two species have been collected off Mexican oceanic islands (see Table 2). It should be noted, however, that the Gulf of California southern limit 
used in table 2 is a line extending from San Lucas Cape (ca $\left.22^{\circ} 53^{\prime} \mathrm{N}, 109^{\circ} 58^{\prime} \mathrm{W}\right)$ to Corrientes Cape $\left(20^{\circ} 24^{\prime} 44^{\prime \prime} \mathrm{N}\right.$, $105^{\circ} 43^{\prime} 38^{\prime \prime} \mathrm{W}$ ), on the southern edge of Banderas Bay (see Hendrickx et al., 2005). Consequently, the record of Molpadia granulata off Mazatlán (ca $23^{\circ} 13^{\prime} \mathrm{N}$, $106^{\circ} 27^{\prime} \mathrm{W}$ ), a locality sometimes considered as being outside the Gulf limits, allows us to include it in the Gulf of California species list. Parker (1964) included 17 species living deeper than $350 \mathrm{~m}$ in this data base: Peniagone sp. could correspond to any of the 3 species reported for deep water in the Central eastern Pacific (see Maluf, 1988). Psychropotes dubiosa and P. raripes are now considered junior synonyms of $P$. longicauda, and Parker' $\mathrm{s}$ information is therefore considered as valid record for the later species in the California Current and along SW Mexico. The record for $S$. sagamiensis should be taken with care due to the difficulty to properly identify species in this genus. In this survey we collected 3 species cited by Parker (i.e., B. sanguinolenta, Y. bitentaculata, and $M$. musculus). Seven of the 23 "Mexican" species reported by Maluf (1988) were collected during this survey (see Table 2). Peniagone leander was described after Maluf (1988) had completed her search but has not been found off Mexico. The contribution by Solís-Marín et al. (1997) refers to 3 records of deep-water species off SW Baja California (Laetmogone scotoeides, Pannychia moseleyi and Paracaudina chilensis) (see Table 2). The record of L. scotoeides, however, is in error (F. Solís-Marín, pers. comm.). Within the Gulf of California, Maluf and Brusca (2005) have reported 57 species of Holothuroidea, most from shallow water. Eight deep-water ( $>350 \mathrm{~m}$ depth) species are included in their list, all previously included in Maluf's 1988 list of species (see Table 2).

Compilations by Solís-Marín et al. (2005) and HoneyEscandón et al. (2008) include, when combined, 55 species of Holothuroidea for Pacific Mexico. Unfortunately, depth ranges were not indicated in these lists, but review of bathymetric records available in literature indicates that 6 of these species are from water deeper than $350 \mathrm{~m}$ (see Table 2), all also previously reported by Maluf (1988) for the Gulf of California. In their synopsis of the Gulf of California Holothuroidea, Solís-Marín et al. (2009) include 11 species with bathymetric range reaching depths greater than $350 \mathrm{~m}$. We believe, however, that the following 5 records are either doubtful [i.e., Cucumaria crax Deichmann, 1941; Pseudocnus californicus (Semper, 1868); Holothuria leucospilota (Brands, 1835); Parastichopus californicus (Stimpson, 1857)] or need to be verified (i.e., Chiridota aponocrita H.L. Clark, 1920, which depth information was taken from another species) (see Appendix I). Holothuria leucospilota, for example, a very common species throughout the Indo-Pacific Ocean, is known as an intertidal species with a maximal depth record of $10 \mathrm{~m}$ (Samyn and Massin, 2003). The $695 \mathrm{~m}$ cited by Solís-Marín et al. (2009) seems unlikely. We have considered as valid only the record for Abyssocucumis albatrossi (cited as Stereocucumis abyssorum; however, presence of spiny arms on the ossicles indicates the material belongs to A. albatrossi), Pannychia moseleyi, Molpadia intermedia, and M. musculus, all 4 species collected during this survey, and for Scotoplanes clarki and Heldingia californica (see Table 2), not collected during the TALUD cruises. Finally, a new deep water species of Synallactes was recently described from the Gulf of California (Massin and Hendrickx, 2010) and has also been included in the list of Mexican species (Table 2).

The capture of 1 large specimen of Abyssocucumis albatrossi in the central Gulf of California confirms the presence of a second species of the genus in Mexican waters and is the first confirmed record for the Gulf. The rediscovery of Psolidium gracile, reported only once from off California since its original description, based on material from off Panama, allows us to report it from off SW Mexico and within the Gulf of California. Laetmogone scotoeides was previously known only from the type locality, SE of Ballenas Bay, in the California Current area, and is now cited for SW Mexico. The large series of specimens of Pannychia moseleyi collected during this survey confirms the abundance and high occurrence of this species along western Mexico. Synallactes alexandri is recorded for the first time in Mexican waters.

\section{Ecology}

For most species studied herein, depth and epibenthic water temperature are similar to the data available in the literature (e.g., Ludwig, 1894; H.L. Clark, 1913, 1920; Parker, 1964). Information on epibenthic dissolved oxygen concentration at sampling sites is rarely available for deepwater species. In this study, focused on the fauna living at the edge and below the minimum oxygen zone off the Pacific coast of Mexico, we were able to measure close-tobottom oxygen concentration associated with the capture of Holothuroidea (Table 1). These data indicate adaptation to mild hypoxic conditions for Laetmogone scotoeides (0.68$\left.1.01 \mathrm{ml} \mathrm{O}_{2} / \mathrm{l}\right)$ and to more severe hypoxic condition for Psolus squamatus (0.26-0.36 $\left.\mathrm{ml} \mathrm{O}_{2} / 1\right)$, Molpadia musculus (0.15-0.40 $\left.\mathrm{ml} \mathrm{O}_{2} / 1\right)$, and both species of Synallactes $(0.20$ $\left.\mathrm{ml} \mathrm{O}_{2} / 1\right)$. It is to be noted, however, that Molpadia musculus has been reported by Parker (1964) in dissolved oxygen concentration of $1.80-2.00 \mathrm{ml} \mathrm{O} / 1$ in localities just north and south of Mexico. Mitsukuriella unusordo sp. nov. was also collected in low oxygen concentration $\left(0.32 \mathrm{ml} \mathrm{O}_{2} / \mathrm{l}\right)$ but additional information is needed to confirm its affinity 
to a hypoxic environment. Some species were collected in a wide range of dissolved oxygen values (Psolidium gracile, $<0.05-1.05 \mathrm{ml} \mathrm{O}_{2} / 1$; Yspilocucumis californiae sp. nov., 0.20-1.40 $\mathrm{ml} \mathrm{O} / 2$; Pannychia moseleyi, 0.11$\left.1.38 \mathrm{ml} \mathrm{O}_{2} / 1\right)$ corresponding to a wide bathymetric range, thus indicating the possibility for these species to extend their vertical distribution from the edge of the anoxic zone into deeper water. Moereover, the number of $P$. gracile collected in 2 stations (i.e., 6 specimens in St. 17, TALUD IX, and 17 in St. 1, TALUD XI) indicates that this species can be abundant in this habitat. Benthodytes sanguinolenta, a species occurring mostly below $2000 \mathrm{~m}$ depth, was collected at a similar depth, in relatively well oxygenated waters (i.e., $1.61 \mathrm{ml} \mathrm{O}_{2} / 1$ ) during this survey, and its known range of tolerance to oxygen concentration is $1.30-2.80 \mathrm{ml}$ $\mathrm{O}_{2} / 1$ (Parker, 1964). The unique locality where Ypsilothuria bitentaculata and Abyssocucumis albatrossi were found features similar environmental conditions (1 925-1977 m, $1.43 \mathrm{mlO}_{2} / 1$ for the former; $2056-2195 \mathrm{~m}, 1.68 \mathrm{ml} \mathrm{O} / 1$ for the latter). Off western Mexico, oxygen concentrations increase to values superior to $1.50 \mathrm{ml} \mathrm{O}_{2} / 1$ below 2000 $\mathrm{m}$, and this might indicate that $B$. sanguinolenta, $Y$. bitentaculata, and Abyssocucumis albatrossi are not able to tolerate the low oxygen concentrations found in shallower water (i.e., between 700 and $1300 \mathrm{~m}$ where oxygen values range from almost zero to ca $1.00 \mathrm{ml} \mathrm{O}_{2} / \mathrm{l}$ ) (Table 1) (see Hendrickx, 2001; Hendrickx and Serrano, 2010). Off Oregon, these species were collected below $2000 \mathrm{~m}$, also much deeper that the oxygen minimum zone occurring in that area (Carney and Carey, 1976). The possibility for several species of deep-water holothurians to survive in severe or extreme hypoxic conditions represents a decisive advantage with regards to competition for food or potential predators. On the other hand, as noted by Alton (1972) and Carney and Carey (1976) off Oregon, the presence of a minimum oxygen zone might serve as a physiological barrier to both upward and downward extension of range for many species, a similar pattern to the one described for shrimp (Dendrobranchiata and Caridea) along the west coast of Mexico (Hendrickx and Serrano, 2010). Still, it is interesting to note that the 2 stations where more than 1 species of Holothuroidea were found during this survey experienced severe hypoxia (see Table 1).

\section{Distribution and biodiversity}

Comparison with neighbouring areas. There are few recent data available to compare the material collected during the TALUD survey with the rest of the Central eastern Pacific. Bluhm (1994) reported on holothurians collected in manganese module sites off northern Peru (ca $90^{\circ} \mathrm{W}$ ) and in the central Pacific, but none of his species (most identified to genus) matches with the TALUD material. Bluhm and Gebruk (1999) reported 20 holothurian species observed by means of a remote control camera in the Peru Basin, roughly between 3800 and $4200 \mathrm{~m}$ depth. Many species were identified to genus level, and only 1 species, Benthodytes sanguinolenta, coincides with our study. Pawson and Ahearn (2001) studied a small series of holothurians collected off the Galapagos Islands and reported the presence of 7 species, 3 probably undescribed and only 1 (Pannychia moseleyi) common with our study.

On the other hand, there has been a large series of surveys of the megafauna on the continental slope and abyssal plains off the west coast of the USA, using both conventional trawls and camera sled. A comparative analysis of the composition of the Holothuroidea fauna collected in this area is provided by Nybakken et al. (1998). According to this review, the highest species richness was reported by Carney and Carey (1976) off Oregon, who reported 28 species below the continental shelf zone ( $>300 \mathrm{~m}$ to the 4 $000 \mathrm{~m}$ depth range). Six of these species were found during the TALUD project, including 2 species (i.e., A. albatrossi and $B$. sanguinolenta) reported by these authors only in water much deeper $(>2700 \mathrm{~m})$ than in our study. Carney and Carey (1982) collected 22 species of Holothuroidea between 2162 and $3961 \mathrm{~m}$ on Cascadia Basin and Tufts Abyssal Plain, off Oregon, including 5 species $(A$. albatrossi, B. sanguinolenta, P. moseleyi, M. musculus, and $Y$. bitentaculata) found during the TALUD project in much shallower waters. Of the 13 species collected by Nybakken et al. (1998) off central California, 6 were found during the TALUD cruises. Quite remarkably, these 6 species are the same as those common between the "1976" Oregon and the TALUD surveys. A more recent survey along the coast of California, Oregon and Washington, detected the presence of 8 deep-water species ranging to 721-1 $285 \mathrm{~m}$ depth, including Molpadia intermedia, Pannychia moseleyi, and Psolus squamatus, all 3 considered among the moderatelyfrequent species (Keller et al., 2007). According to Lambert (2007), there are 45 species of sea cucumbers reported for British Columbia, 34 occurring below $200 \mathrm{~m}$. His list includes Pannychia moseleyi, Ypsilothuria bitentaculata, Psolus squamatus, and Molpadia intermedia, but the former 2 are only found above $200 \mathrm{~m}$ off British Columbia. Including the material collected during the TALUD survey, the deep-water $(>350 \mathrm{~m})$ Holothuroidea fauna occurring of the Pacific coast of Mexico comprises of 31 species, a number quite similar to those numbers reported for Oregon (28 in $>300 \mathrm{~m}$ ) and British Columbia (34 in $>200 \mathrm{~m}$ ), but apparently higher than those reported for California.

Comparison with remote areas. If we compare deep-water species richness from the Philippines(Cherbonnier and Féral, 1981) and the Rockall Trough (U.K.) (Gage et 
al., 1985) with Pacific Mexico (all 3 with similar sampling depth: 379-1 125, 400-2 900, and 350-2 200, respectively), the Philippines and the U.K. areas appear much richer. The number of species per number of samples is 1.20 for the Philippines, 0.97 for U.K. and only 0.09 for Mexico. This difference, of an order of magnitude of 10 , could be linked to the limiting effect of the Pacific Mexico OMZ, which is not present in the 2 other areas. Rockall Trough and the Mexican Pacific differ also drastically by their holothurian species composition. Of the 34 and 31 species collected respectively only 2 are shared, i.e. Psychropotes longicauda and Ypsilothuria bitentaculata.

Even considering the strong limitations of this study (i.e., reduced number of days at sea and samples, sampling depth, extension of the study area), the TALUD exploratory survey initiated in 1989, with major collecting efforts in 2000-2001 and 2005-2008, represents one of the most important event for the knowledge of deep-water Holothuroidea of western Mexico since the "Albatross" collected material between Guatemala and the southern Gulf of California, in 1891-92. There have been very few recent studies of deep-water Holothuroidea (and other Echinodermata) in the East Pacific. Yet, every single study has fully demonstrated that even limited sampling effort on the bathyal seafloor can bring very interesting results, particularly considering the impact of the Minimum Oxygen Zone on the composition and distribution of the deep-water benthic communities in the East Pacific.

\section{Acknowledgments}

The authors thank all scientists, students and crew members who took an active part into the TALUD cruises aboard the R/V "El Puma". One of us (MEH) is grateful to the Royal Belgian Institute of Natural Sciences for its hospitality during his sabbatical leave, to Thierry Backeljau and Claude Massin for their invitation, and to the DGAPA, PASPA, UNAM, Mexico, for supporting his sabbatical stay. We thank Harim Cha, SCRIPPS Institution of Oceanography, La Jolla, for the loan of specimens, José Salgado Barragán for his technical support during the study of the material, A. Van Haelen for the photographs of plate 1. Gordon Hendler provided data related to Allan Hancock expeditions material, and Mercedes Cordero made the final edition of the manuscript. Thanks to our colleagues and friends Manuel, Sammy, José-Antonio and David U., and to R. García-Tenorio and J. Ontiveros for helping with availability of specimens. This project was partly supported by CONACyT, Mexico (project 31805N) and DGAPA (project IN-217306-3), UNAM, Mexico.

\section{Literature cited}

Alton, M. S. 1972. Bathymetric distribution of echinoderms off the Northern Oregon Coast. In The Columbia River Estuary and Adjacent Ocean Waters, A. T. Pruter and D. L. Alverson (eds.). University of Washington Press, Seattle p. 475-536.

Anonymous. 2004. SCAMIT Newsletter. 23:1-8.

Belyaev, G. M. 1971. Deep water holothurians of the genus Elpidia. In Fauna of the Kurile-Kamchatka Trench and its environment, Vol. 92 (in Russian), V. Grigor'yevich Bogorov (ed.). Trudy Instituta Okeanologii, P.P. Shirshova. p. 326-367.

Bergen, M. 1980. Holothuroidea. In A taxonomic listing of common marine invertebrate species from Southern California, D. Straugham and R. W. Klink (eds.). Technical Reports of the Allan Hancock Foundation 3:274-277.

Bluhm, H. 1994. Monitoring megabenthic communities in abyssal manganese nodule sites of the East Pacific Ocean in association with commercial deep-sea mining. Aquatic Conservation: Marine and Freshwater Ecosystems 4:187201.

Bluhm, H. and A. Gebruk. 1999. Holothuroidea (Echinodermata) of the Peru Basin - ecological and taxonomic remarks based on underwater images. Marine Ecology 20:167-195.

Borrero-Peréz, G. H, M. Benavides-Serrato, O. D. Solano and G. R. Navas. 2005. Holothuroideos (Echinodermata: Holothuroidea) recolectados en el talud continental superior del Caribe colombiano. Boletín del Instituto Oceanográfico, Universidad de Oriente, Venezuela 42:65-85.

Carney, R. S. and A. G. Carey, Jr. 1976. Distribution pattern of holothurians on the Northeastern Pacific (Oregon, U.S.A.) continental shelf slope, and abyssal plain. Thalassia Jugoslavica 12:67-74.

Carney, R. S. and A. G. Carey, Jr. 1982. Distribution and diversity of holothuroids (Echinodermata) on Cascadia Basin and Tufts Abyssal Plain. Deep-Sea Research 29:597-607.

Caso, M. E. 1961. Estado actual de los conocimientos acerca de los equinodermos de México. Tesis doctorado, Facultad de Ciencias, Universidad Nacional Autónoma de México, México, D.F. 388 p.

Caso, M. E. 1964. Contribución al conocimiento de los Holoturoideos de México. Descripción de un nuevo subgénero del género Holothuria. Holothuria (Paraholothuria) y de una nueva especie Holothuria riojae. Anales del Instituto de Biología, Universidad Nacional Autónoma de México 33:367-380.

Caso, M. E. 1966. Estudios sobre Equinodermos de México. Contribución al conocimiento de los Holoturoideos de Zihuatanejo y de la Isla de Ixtapa (primera parte). Anales del Instituto de Biología, Universidad Nacional Autónoma de México, Serie Ciencias del Mar y Limnología 36:253-291.

Caso, M. E. 1968. Contribución al estudio de los Holoturoideos de México. La familia Psolidae. Descripción de una nueva 
especie del género Psolus, Psolus conchae sp. nov. Anales del Instituto de Biología, Universidad Nacional Autónoma de México, Serie Ciencias del Mar y Limnología 39:1-20.

Cherbonnier, G. 1941. Étude anatomique et biogéographique sur deux Cucumaria abyssaux: C. abyssorum Théel et $C$. albatrossi n. sp. Bulletin du Muséum national d'Histoire naturelle (Paris) ser. 2, 13:93-103.

Cherbonnier, G. 1947. Note sur une holothurie abyssale: Abyssocucumis ingolfi (Deichmann, 1927). Bulletin du Muséum national d'Histoire naturelle (Paris) ser. 2, 19:459463.

Cherbonnier, G. and J-P. Féral, 1981. Echinodermes: Holothuries. In Résultats des Campagnes MUSORSTOM. I. Philippines (18-28 mars 1976). Tome 1. Collection Mémoires ORSTOM 91:357-412.

Clark, H. L. 1907. The Apodous holothurians. A monograph of the Synaptidae and Molpadiidae. Smithsonian Contributions to Knowledge 35:1-206.

Clark, H. L. 1913. Echinoderms from Lower California, with descriptions of new species. Bulletin of the American Museum of Natural History 32:185-236.

Clark, H. L. 1920. Holothuroidea. Report XXXII on the Scientific Results of the Expedition of the "Albatross" to the Tropical Pacific, 1899-1900 and 1904-1905. Memoirs of the Museum of Comparative Zoology at Harvard College 39:121-154.

Clark, H. L. 1923. Echinoderms from Lower California, with descriptions of new species: Supplementary report. Bulletin of the American Museum of Natural History 48:147-163.

Deichmann, E. 1930. The holothurians of the western part of the Atlantic Ocean. Bulletin of the Museum of Comparative Zoology Harvard 71:43-226.

Deichmann, E. 1937. Holothurians from the Gulf of California, the west coast of Lower California and Clarion Island. Zoologica, N.Y. 22:161-176.

Deichmann, E. 1938a. New holothurians from the western coast of North America, and some remarks on the genus Caudina. Proceedings of the New England Zoological Club 17:23-25.

Deichmann, E. 1938b. New records of Paracaudina chilensis (J. Müller) from the west coast of Central America and Mexico. Proceedings of the New England Zoological Club 16:103115 .

Deichmann, E. 1938c. Holothurians from the western coasts of Lower California and Central America, and from the Galapagos Islands; Eastern Pacific Expeditions of the New York Zoological Society. Zoologica, N.Y. 23:361-387.

Deichmann, E. 1941. The Holothuroidea collected by the "Velero" III during the years 1932 to 1938. Part 1. Dendrochirota. Allan Hancock Pacific Expeditions 8:61-153.

Deichmann, E. 1954. The holothurians of the Gulf of Mexico. Bulletin of the United States Fishery Commission 55:381-41.

Domantay, J. S. 1953. A brief summary of the Pacific and Atlantic Holothuroidea of the Allan Hancock Foundation Collections.
Philippine Journal of Science 82:133-140.

Domantay, J. S. 1961. New forms of Holothuroidea from the vicinity of Southern California and Mexico in the collection of the Allan Hancock Foundation, University of Southern California. Philippine Journal of Science 90:333-346.

Ekman, S. 1923. Über Psolus squamatus und verwandte Arten. Zugleich ein Beitrag zur Bipolaritätsfrage. Arkiv för Zoölogie 15:1-59.

Gage, J.D., D.S.M. Billett, M. Jensen and P.A. Tyler. 1985. Echinoderms of Rockall Trough and adjacent areas.2. Echinoidea and Holothurioidea. Bulletin of the British Museum (Natural History), Zoology 48:173-213.

Gebruk, A.V. 1990. Deep-Sea holothurians of the family Elpidiidae. Akademia Nauka, Moscow, URSS. 160 p. [In Russian].

Grassle, J. F. 1989. Species diversity in deep-sea communities. Trends in Ecology and Evolution 4:12-15.

Haney, L. 2004. Holothuroidea. SCAMIT Newsletter 23:10-30.

Hansen, B. 1975. Systematics and Biology of the Deep-Sea Holothurians, Part 1: Elasipoda. Galathea Reports 13:1-262.

Hansen, B. 1988. The genus Staurocucumis Ekman and its possible affinity with Echinocucumis Sars (Holothuroidea, Dendrochirota). In Echinoderm Biology, R.D. Burke, P.V. Madlenov, P. Lambert and R.I. Parsley (eds.). Balkema, Rotterdam p. 301-308.

Heding, S.G. 1931. On the classification of the Molpadids. Videnskabelige Meddelelser fra Dansk naturhistorisk Forening i Kóbenhavn 92:275-284.

Heding, S.G. 1942. Holothurioidea. II. Danish Ingolf-Expedition 4:1-39.

Heding, S.G. and A. Panning. 1954. Phyllophoridae. Ein Bearbeitung der polytentaculaten dendrochiroten Holothurien des zoologischen Museums in Kopenhagen. Spolia Zoologica Musei Hauniensis XIII:1-209.

Hendrickx, M. E. 2001. Occurrence of a continental slope decapod crustacean community along the edge of the minimum oxygen zone in the southeastern gulf of California, Mexico. Belgian Journal of Zoology 131:95-109.

Hendrickx, M. E. and D. Serrano. 2010. Impacto de la zona de mínimo de oxígeno sobre los corredores pesqueros en el Pacífico mexicano. Interciencia. 35:12-18.

Hendrickx, M. E., R. C. Brusca and L. T. Findley. 2005. A Distributional Checklist of the Macrofauna of the Gulf of California, Mexico. Part I. Invertebrates. [Listado y Distribución de la Macrofauna del Golfo de California, México, Parte I. Invertebrados]. M. E. Hendrickx, R. C. Brusca and L. T. Findley (eds.). Arizona-Sonora Desert Museum. Tucson, AZ, USA. 429 p.

Hessler, R. R. and H. L. Sanders. 1967. Faunal diversity in the deep sea. Deep-Sea Research 14:65-78.

Honey-Escandón, M., F. A. Solís-Marín and A. LaguardaFigueras. 2008. Equinodermos (Echinodermata) del Pacífico 
Mexicano. Revista de Biología Tropical 56 (Suppl. 3):57-73.

Imaoka, T. 1980. Observations on Psolus squamatus (Koren) from the Okhotsk Sea (Dendrochirota: Psolidae). Publications of the Seto Marine Biological Laboratory 25:361-372.

Keller, A. A., V. H. Simon, B. H. Homess, J. R. Wallace, V. J. Tuttle, E. L. Fruh, K. L. Bosley, D. M. Kamikawa and J. C. Buchaman. 2007. The 2003 U.S. West Coast bottom trawl survey of groundfish resources off Washington, Oregon, and California: Estimates of distribution, abundance, and length composition. U.S. Department of Commerce, NOAA Technical Memo. NMFS-NWFSC-86. 130 p.

Koehler, R. and C. Vaney. 1905. II. Les Holothuries Littorales. In An account of the littoral Holothurioidea collected by the R.I.M.S.S. "Investigator". Echinoderma of the Indian Museum, Part IV, Holothurioidea. Indian Museum, Calcuta p. $1-123$.

Koren, J. 1845. Beskrivelse over Thyone fusus og Cuviera squamata. Nyt Magazin for Naturvidenskaberne 4:203-225.

Lambert, P. 1986. Northeast Pacific holothurians of the genus Parastichopus with a description of a new species Parastichopus leukothele (Echinodermata). Canadian Journal of Zoology. 64:2266-2272.

Lambert, Ph. 1996. Psolidium bidiscum, a new shallow water, psolid sea cucumber (Echinodermata: Holothuroidea) from the northeast Pacific, previously misidentified as Psolidium bullatum Ohshima. Canadian Journal of Zoology 74:20-31.

Lambert, Ph. 1997. Sea cucumbers of British Columbia, Southeast Alaska and Puget Sound. University of British Columbia Press, Vancouver. 166 p.

Lane, D. J. W., L. M. Marsh, D. VandenSpiegel and F. W. E. Rowe. 2000. Echinoderm fauna of the South China Sea: an inventory and analysis of distribution patterns. The Raffles Bulletin of Zoology Supplement 8:459-493.

Levin, L. A. and J. D. Gage. 1998. Relationships between oxygen, organic matter and the diversity of bathyal macrofauna. Deep-Sea Research II 45:129-163.

Levin, L. A., R. J. Etter, M. A. Rex, A. J. Gooday, C. R. Smith, J. Pineda, C. T. Stuart, R. R. Hessler and D. Pawson. 2001. Environmental influences on regional deep-sea species diversity. Annual Review Ecology System 32:51-93.

Ludwig, H. 1893. Vorläufiger Beritch über die auf den TiefseeFahrten des "Albatross" (Fruhling 1891) im östlichen Stillen Ocean erbeuteten Holothurien. Zoologischer Anzeiger 16:177-186.

Ludwig, H. 1894. Reports of an Exploration off the West Coast of Mexico, Central and South America, and off the Galapagos Islands, in Charge of Alexander Agassiz, by the U.S. Fish Commission Steamer "Albatross", during 1891, Lieutenant Commander Z.L. Tanner, U.S.N., Commanding, XII: The Holothurioidea. Memoirs of the Museum of Comparative Zoology at Harvard College 17:1-183.

Ludwig, H. 1900. Arktische und subarktische Holothurien.
Chapter V. In Fauna Arctica, F. Römer and F. Schaudin (eds.). Gustav Fisher, Jena 1900 1:134-178.

Ludwig, H. and S. G. Heding. 1935. Die Holothurien der Deutschen Tiefsee-Expedition. 1. Fusslose und dendrochirote Formen. Wissenschaftliche Ergebnisse der Deutschen Tiefsee-Expedition auf dem Dampfer Valdivia 1898-1899 24:123-214.

Luke, S. R. 1982. Catalog of the Benthic Invertebrate Collections, Echinodermata. Scripps Institution of Oceanography Reference Series, No. 82-5. University of California. 71 p.

Lütken, Chr. 1857. Oversigt over Grölands Echinodermata. Videnskabelige Meddelelser fra Dansk naturhistorisk Forening i Kóbenhavn 1857:1-55.

Madsen, F. J. 1955. Holothuroidea. Reports of the Swedish DeepSea Expedition, Part II. Zoology 12:151-173.

Madsen, F. J. and B. Hansen. 1994. Echinodermata Holothurioidea. Marine invertebrates of Scandinavia, 9. Scandinavian University Press. Oslo, Norway. 143 p.

Maluf, L. I. 1988. Composition and distribution of the Central eastern Pacific Echinoderms. Technical Report, Natural History Museum of Los Angeles County 2:1-242.

Maluf, L. Y. 1991. Echinoderm Fauna of the Galapagos Islands. Chapter 16. In Galapagos Marine Invertebrates: Taxonomy, Biogeography and Evolution in Darwin's Islands, M. J. James (ed.). Plenum Press, New York p. 345-367.

Maluf, L. I. and R. C. Brusca. 2005. Echinodermata. Chapter 18. In A Distributional Checklist of the Macrofauna of the Gulf of California, Mexico. Part I. Invertebrates. [Listado y Distribución de la Macrofauna del Golfo de California, México, Parte I. Invertebrados], M. E. Hendrickx, R. C. Brusca and L. T. Findley (eds.). Arizona-Sonora Desert Museum, Tucson, Az. USA p. 327-343.

Massin, C. 1994. Ossicle variation in Antarctic dendrochirote holothurians (Echinodermata). Bulletin de l'Institut Royal des Sciences Naturelles de Belgique, Biologie 64:129-146.

Massin, C. 1996. Holothuries (Echinodermata) récoltées sur le talus continental méditerranéen lors de la Campagne DEPRO 96. Mésogée 55:43-48.

Massin, C. and M. E. Hendrickx. 2010. A new species of deep-water Holothuroidea (Echinodermata) of the genus Synallactes from off western Mexico. Scientia Marína 74:599-603.

McClain, C. R. 2004. Connecting species richness, abundance and body size in deep-sea gastropods. Global Ecology Biogeography 13:327-334.

McClain, C. R. and M. A. Rex. 2001. The relationship between dissolved oxygen concentration and maximun size in deepsea turrid gastropods: an application of quantile regression. Marine Biology 139:681-685.

Méndez, N. 2006. Deep-water polychaetes (Annelida) from the southeastern Gulf of California, Mexico. Revista de Biología Tropical 54:773-785. 
Mitsukuri, K. 1912. Studies on Actinopodous Holothurioidea. Journal of the College of Science, Tokyo Imperial University 29:1-284.

Mortensen, T. 1925. On a small Collection of Echinoderms from the Antarctic Sea. Arkiv för Zoologi 17A:1-12.

Mortensen, T. 1927. Handbook of the echinoderms of the British Isles. Humphrey Milford, Oxford University Press, London. $471 \mathrm{p}$.

Müller, J. 1850. Anatomische Studien über die Echinodermen. Archiv für Anatomie und Physiologie. 1850:115-155; 225233.

Müller, O. F. 1776. Zoologiae Danicae Prodromus, Havniae 1776. Copenhagen $274 \mathrm{p}$.

Nybakken, J. 2010. Deeper bottom habitats. III. Deep Sea Sedimentary Megafaunal Communities (>2000 m depth). http://montereybay.noaa.gov./sitechar/deep3.html (last access: 01.II.2010).

Nybakken, J., S. Craig, L. Smith-Beasley, G. Moreno, A. Summers and L. Weetman. 1998. Distribution density and relative abundance of benthic invertebrate megafauna from 3 sites at the base of the continental slope off central California as determined by camera sled and beam trawl. Deep-Sea Research II 45:1753-1780.

Ohshima, H. 1915. Report on the holothurians collected by the U.S. fisheries steamer "Albatross" in the N.W. Pacific during the summer of 1906. Proceedings of the United States National Museum 48:213-291.

Olabarria, C. and M. H. Thurston. 2003. Latitudinal and bathymetric trends in body size of the deep-sea gastropod Troschelia barniciensis (King). Marine Biology 143:723-730.

Olabarria, C. and M. H. Thurston. 2004. Patterns of morphological variation of the deep-sea gastropod Troschelia berniciensis (King, 1846) (Buccinidae) from the northeastern Atlantic Ocean. Journal of Molluscan Studies 70:59-66.

O'Loughlin, P. M. 2002. Report on selected species of BANZARE and ANARE Holothuroidea, with reviews of Meseres Ludwig and Heterocucumis Panning (Echinodermata). Memoirs of Museum Victoria 59:297-325.

O'Loughlin P. M., M. E.Manchon-Cabeza and F. Moya Ruiz. 2009. Antarctic holothuroids from the Bellingshausen Sea, with descriptions of new species (Echinodermata: Holothroidea). Zootaxa 2016:1-6.

Östergren, H., 1904. Sitzung den 8 Mai 1903. Zoologische Anzeiger 27:659.

Panning, A. 1949. Versuch einer Neuordnung der Familie Cucumariidae (Holothuroidea; Dendrochirota). Zoologische Jahrbücher. Abteilung für Systematik 78:404-470.

Parker, R. H. 1964. Zoogeography and ecology of some macroinvertebrates, particularly mollusk, in the Gulf of California and the continental slope off Mexico. Videnskabelige Meddelelser fra Dansk naturhistorisk Forening i Kóbenhavn 126:1-178.
Pawson, D. L. 1969. Holothuroidea from Chile. Report No. 46 of the Lund University Chile Expedition 1948-1949. Sarsia 38:121-146.

Pawson, D. L. 1977. Molpadiid sea cucumbers (Echinodermata: Holothuroidea) of the southern Atlantic, Pacific and Indian Oceans. Antarctic Research Series 26:97-123.

Pawson, D. L. 1983. Psychronaetes hanseni, a new genus and species of elasipodan sea cucumber (Echinodermata: Holothuroidea) from the eastern central Pacific. Proceedings of the Biological Society of Washington 96:154-159.

Pawson, D. 2009. Holothuroidea (Echinodermata). In New Zealand Inventory of Biodiversity. Volume One: Kingdom Animalia, D. Gordon. (ed.). Sydney. 584 p.

Pawson, D. L. and E. J. Foell, 1986. Peniagone leander new species, an abyssal benthopelagic sea cucumber (Echinodermata, Holothuroidea), from the eastern central Pacific Ocean. Bulletin of Marine Science 38:293-299.

Pawson, D. L. and C. Ahearn, 2001. Bathyal echinoderms of the Galapagos Islands. In Echinoderms 2000, M. Barker (ed.). A. A. Balkema, Rotterdam. p.41-46.

Pawson, D. L. and H. B. Fell. 1965. A revised classification of the Dendrochirote holothurians. Breviora 214:1-7.

Perrier, R., 1902. Holothuries. In Expéditions Scientifiques du Travailleur et du Talisman pendant les années 1880, 1881, 1882, 1883. Ouvrage publié sous les auspices du Ministère de l'instruction Publique sous la direction de A. MilneEdwards de 1888 à 1890 et continuée par E. Perrier. Masson et Cie, Editeurs, Paris. p. 273-554, 11 plates.

Perrier, R. 1905. Holothuries antarctiques du Muséum d'Histoire Naturelle de París. Annales des Sciences Naturelles Zoologie Ser. 9:1-146.

Rex, M. A. and R. J. Etter. 1998. Bathymetric patterns of body size: implications for deep-sea biodiversity. Deep-Sea Research II 45:103-127.

Risso, A. 1826. Histoire naturelle des principales productions de l'Europe méridionale et particulièrement de celles des environs de Nice et des Alpes Maritimes. Levrault, Paris. 4, 439 p.

Rosenberg, R., W. E. Arntz, E. Chumán de Flores, L. A. Flores, G. Carvajal. I. Finger and J. Tarazona. 1983. Benthos biomass and oxygen deficiency in the upwelling system off Peru. Journal of Marine Research 41:263-279.

Rogers, A. D. 2000. The role of oceanic oxygen minimum zones in generating biodiversity in the deep sea. Deep-Sea Research II 47:119-148.

Samyn, Y, and Cl. Massin, 2003. The holothurian subgenus Mertensiothuria (Aspidochirotida: Holothuriidae) revisited. Journal of Natural History 37:2487-2519.

Sanders, H. L. and R. R. Hessler. 1969. Ecology of the deep-sea benthos. Science 163:1419-1424.

Sastry, D. R. K. 2007. Echinodermata of India: An annotated list. Records of the Zoological Survey of India, Occasional Paper 271:1-387. 
Sibuet, M. 1977. Répartition et diversité des Echinodermes (Holothurides-Astérides) en zone profonde dans le Golfe de Gascogne. Deep-Sea Research 24:549-563.

Smith, C. R., L. A. Levin and S. Mullineaux. 1998. Deepsea biodiversity: a tribute to Robert R. Hessler. Deep-Sea Research II 45:1-11.

Solís-Marín, F. A. 2003. Systematics and phylogeny of the holothurian family Synallactidae. Ph.D. thesis, University of Southampton, UK. 356 p.

Solís-Marín, F. A., H. Reyes-Bonilla, M. D. Herrero-Pérezrul, O. Arizpe-Covarrubias and A. Laguarda-Figueras. 1997. Sistemática y distribución de los equinodermos de la bahía de La Paz. Ciencias Marinas 23:249-263.

Solís-Marín, F. A., A. Laguarda-Figueras, A. Durán-González, C. Gust Ahearn and J. Torres Vega. 2005. Echinoderms (Echinodermata) from the Gulf of California, Mexico. Revista de Biología Tropical 53 (suppl. 3):123-137.

Solís-Marín, F. A., J. A. Arriaga-Ochoa, A. Laguarda-Figueras, S. C. Frontana-Uribe and A. Durán-González. 2009. Holoturoideos (Echinodermata: Holothuroidea) del Golfo de California. Comisión Nacional par el Conocimiento y Uso de la Biodiversidad e Instituto de Ciencias del Mar y Limnología, UNAM, México, D.F. 177 p.

Thandar, AS., 1984. The holothurian fauna of Southern Africa. Ph.D thesis, University of Durban-Westville, Durban. 566 p.

Thandar, A. S. 1998. A new genus and 3 new species of deepsea holothuroids from the west coast of South Africa (Echinodermata). Journal of Zoology, London 244:79-88.

Thandar, A. 2008. Additions to the holothuroid fauna of the southern African temperate faunistic provinces, with descriptions of new species. Zootaxa 1697:1-57.

Théel, H. 1879. Preliminary report on the Holothuridae of the exploring voyage of H.M.S. "Challenger" I. Kunglica Svenska, Vetenskapsasakademiens Handlingar 5:1-20.

Théel, H. 1882. Report on the Holothurioidea dredged by H.M.S. "Challenger" during the years 1873-1876, Part I: Reports of the scientific results of the voyage of H.M.S. "Challenger" 1873-1876, 4:1-176.

Théel, H. 1886. Report on the Holothurioidea dredged by H.M.S. "Challenger" during the years 1873-1876, Part II. Report on the scientific results of the voyage of H.M.S. "Challenger" during the years 1873-76. Zoology 14:1-290.

Tilot, V. 2006. Biodiversité et distribution de la mégafaune. Vol. 2. Atlas photographique annoté des échinodermes de la zone de fractures de Clarion et de Clipperton. Paris, UNESCO/ IOC. IOC Technical Series 69:1-62.

Vaney, C. 1906a. Expédition Antarctique Française (1903-1905) commandée par le Dr. Jean Charcot. Sciences naturelles: Documents scientifiques. Echinodermes. Holothuries. Expédition Antarctique Française, Masson, Paris. 30 p.

Vaney, C. 1906b. Deux nouvelles holothuries du genre Thyone provenant des Orcades du Sud. Bulletin du Muséum national d'Histoire naturelle, Paris 12:400-402.

Verrill, A. E. 1867. Comparison of the tropical echinoderm fauna of the east and west coasts of America. Transactions of the Connecticut Academy of Arts and Sciences 1:339-351.

Verrill, A. E. 1868. Notice of a collection of echinoderms from La Paz, Lower California, with descriptions of a new genus. Transactions of the Connecticut Academy of Arts and Sciences 1:371-376.

Verrill, A. E. 1870. Descriptions of echinoderms and corals from the Gulf of California. American Journal of Science 2:93-100.

Verrill, A. E. 1871a. Additional observations on echinoderms, chiefly from the Pacific coast of America. Transactions of the Connecticut Academy of Arts and Sciences 1:568-593.

Verrill, A. E. 1871b. On the echinoderm fauna of the Gulf of California and Cape San Lucas. Transactions of the Connecticut Academy of Arts and Sciences 1:593-596.

Zamorano, P., M. E. Hendrickx and A. Toledano Granados. 2006. Distribution and ecology of deep-water mollusks from the continental slope, southeastern Gulf of California, Mexico. Marine Biology 150:883-892. 

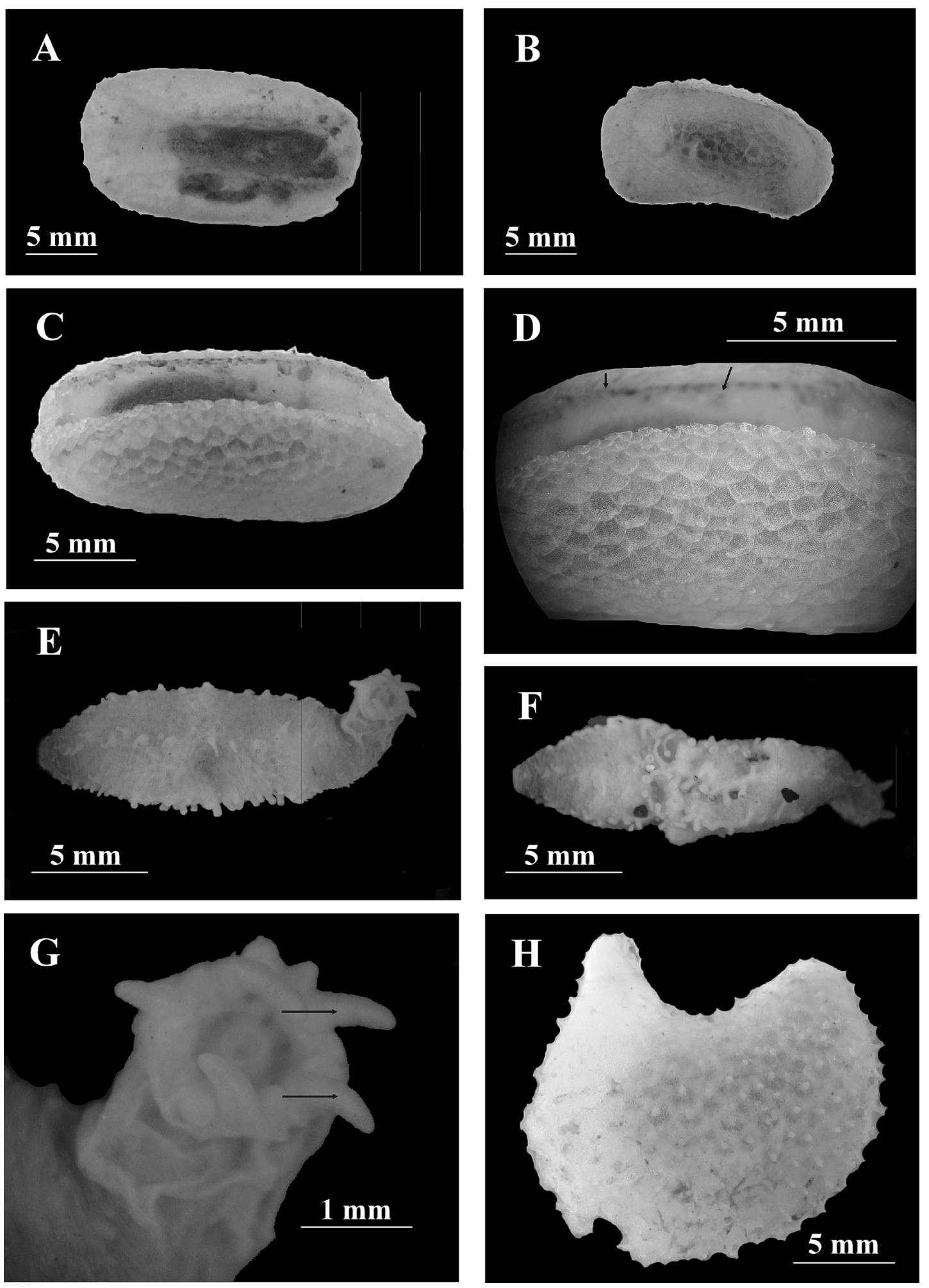

Plate 1. A-D. Psolidium gracile Ludwig, 1894. A: ventral view. B: lateral view. C: lateroventral view. D: detail of lateroventral side (arrows indicate a ventrolateral row of tube feet). E-G. Mitsukuriella unusordo sp. nov.(holotype). E: dorsal view. F: ventral view. G: tentacle crow (arrows indicate long tentacles). H: Ypsilocucumis californiae sp. nov. (holotype) lateral view. 


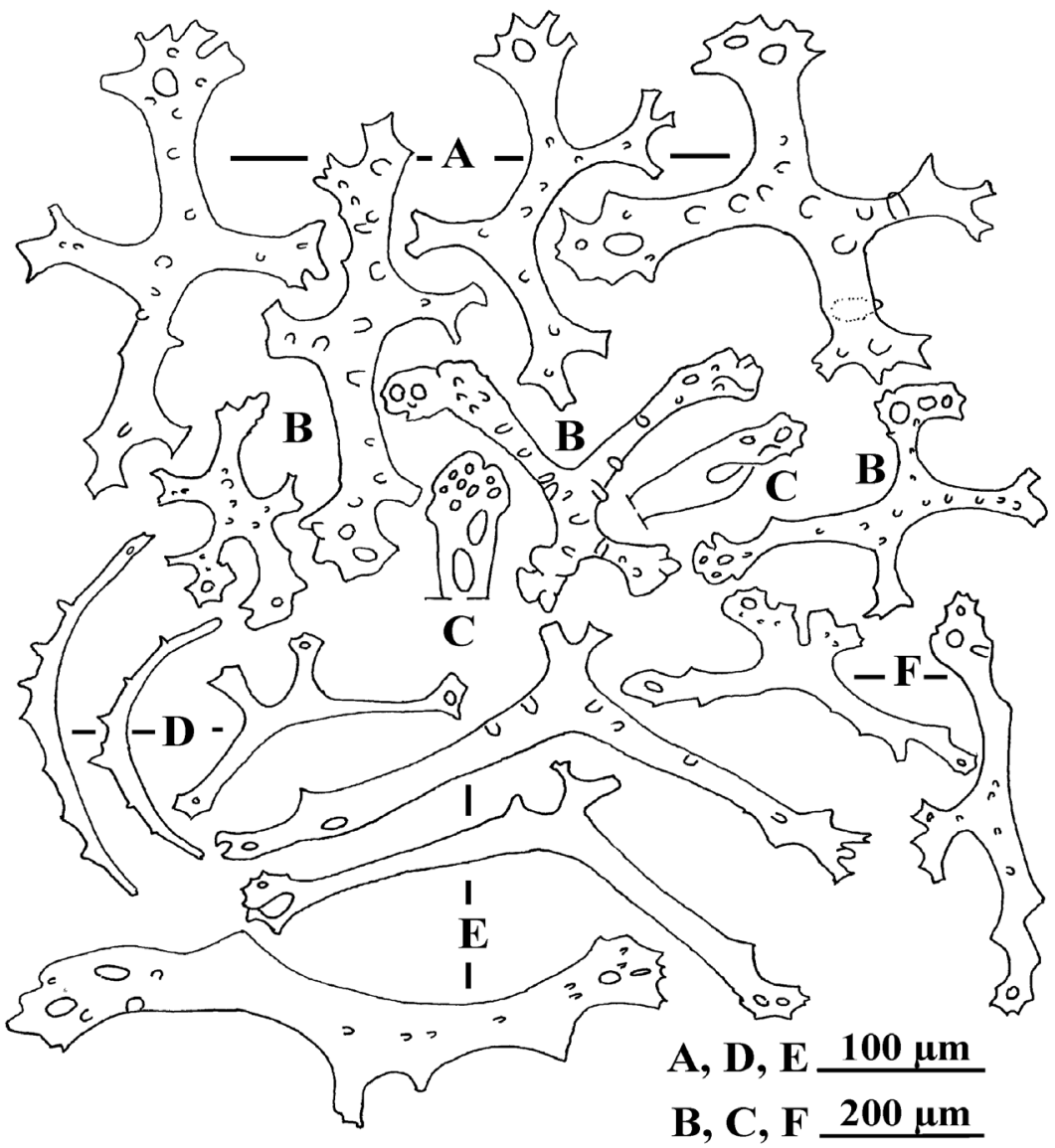

Figure 1. Abyssocucumis albatrossi (Cherbonnier, 1941). A: cross-shaped ossssicles from body wall. B: crossshaped ossicles from tube feet. C: details of the arm's end of B. D: small, curved rods from tentacles. E, F: large rods of the tentacles.
Figure 2. Distribution of examined species of Dendrochirotida off the Pacific coast of Mexico, including previous records (open symbols) and localities where material was collected (solid symbols).

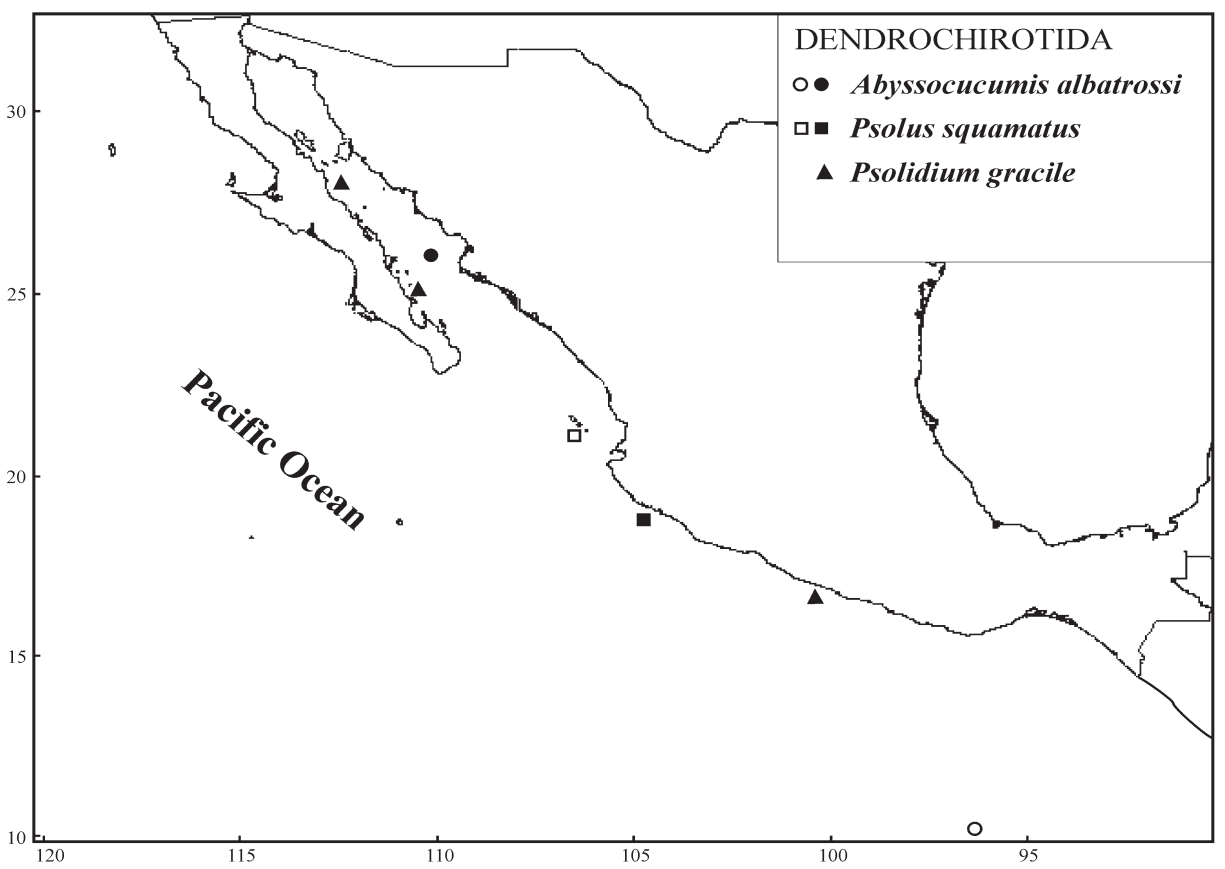




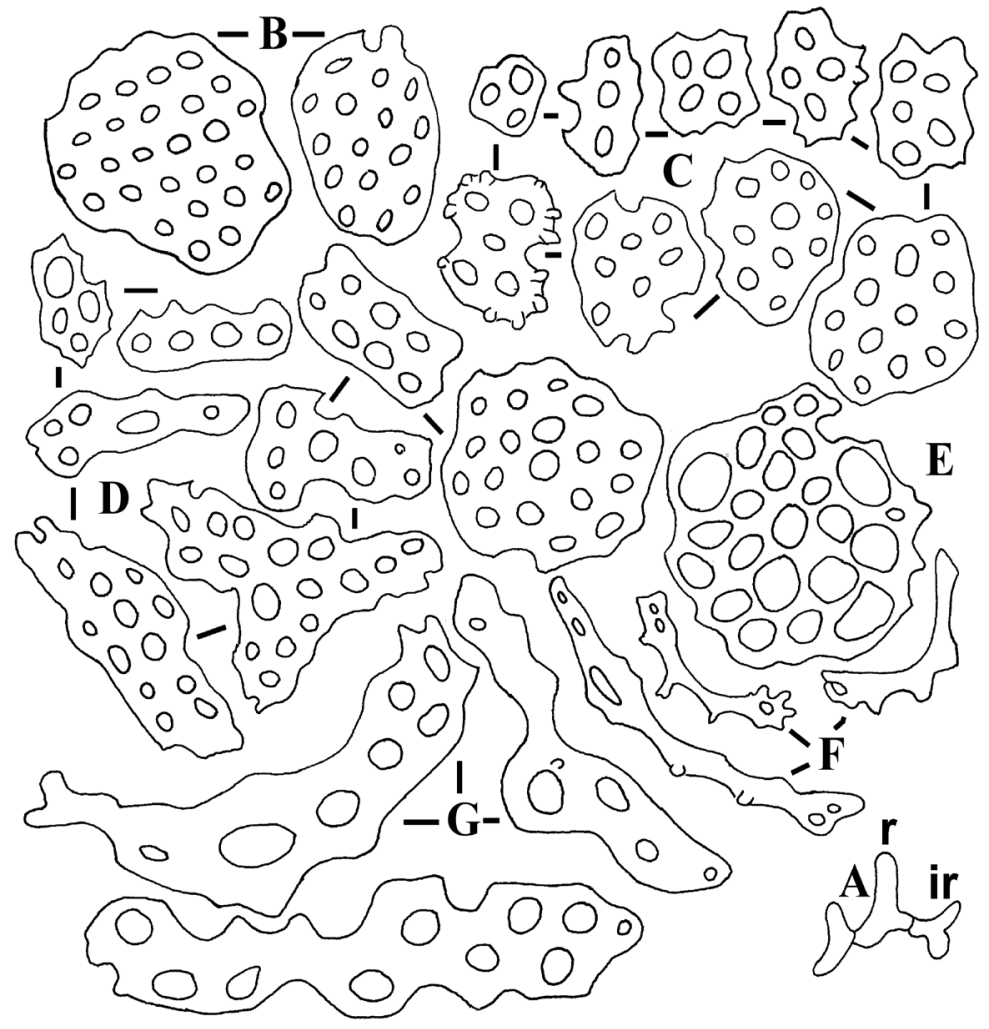

A $1 \underline{\mathrm{mm}} \quad \mathrm{B}, \mathrm{C}, \mathrm{D} \underline{200 \mu \mathrm{m}} \quad \mathrm{F}, \mathrm{E}, \mathrm{G} \underline{100 \mu \mathrm{m}}$
Figure 3. Psolidium gracile Ludwig, 1894. A: calcareous ring (r: radial piece; ir: interradial piece). B: small dorsal scales. C: perforated plates from ventral sole $(\mathrm{L}=16.7 \mathrm{~mm})$. $\mathrm{D}$ : perforated plates from ventral sole $(\mathrm{L}=18.5$ $\mathrm{mm})$. E: end plate of ventral tube feet. F: rods of the ventral tube feet. G: perforated plate of the tube feet.
Figure 4. Psolidium gracile Ludwig, 1894. A: spiny curved rods of the tentacles. B: elongated perforated plates from tentacles. C: details of B extremity. D, E, F: rods of the gonad.

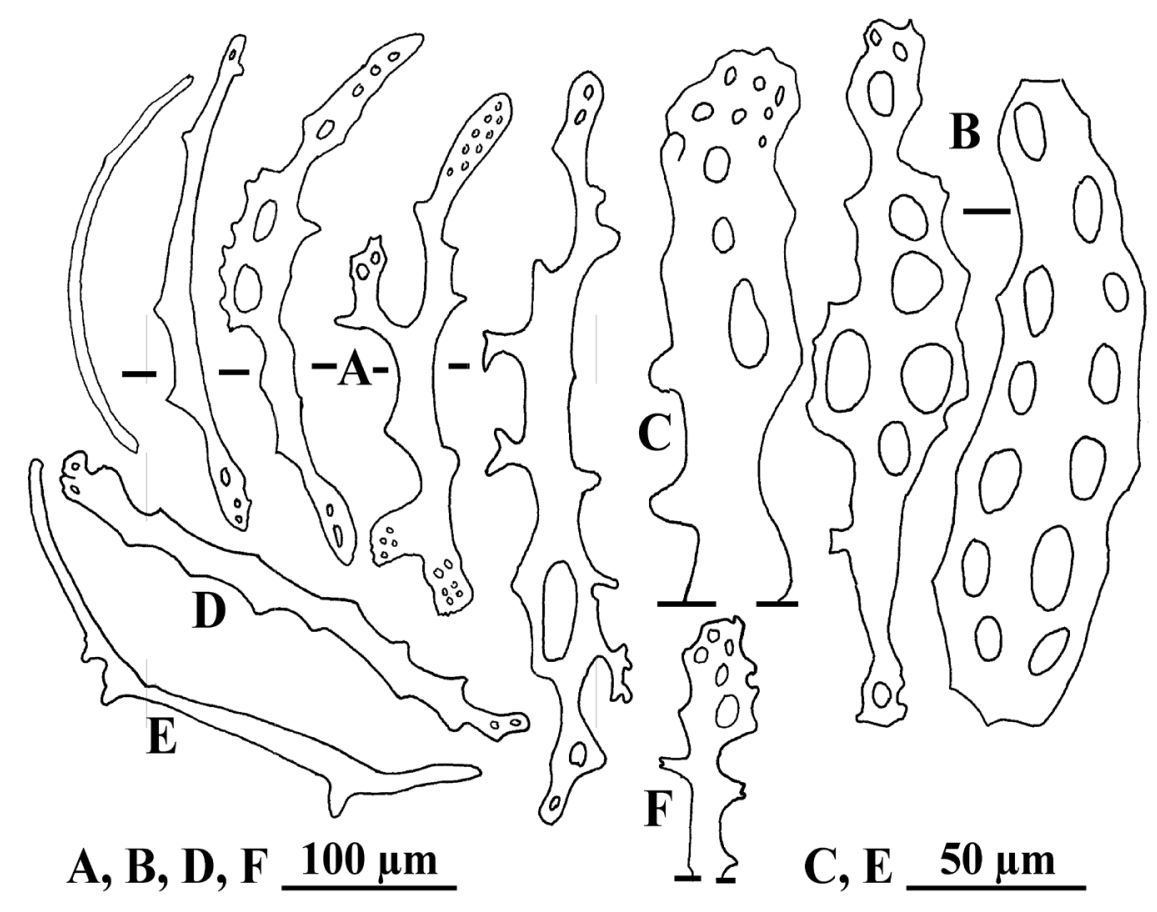




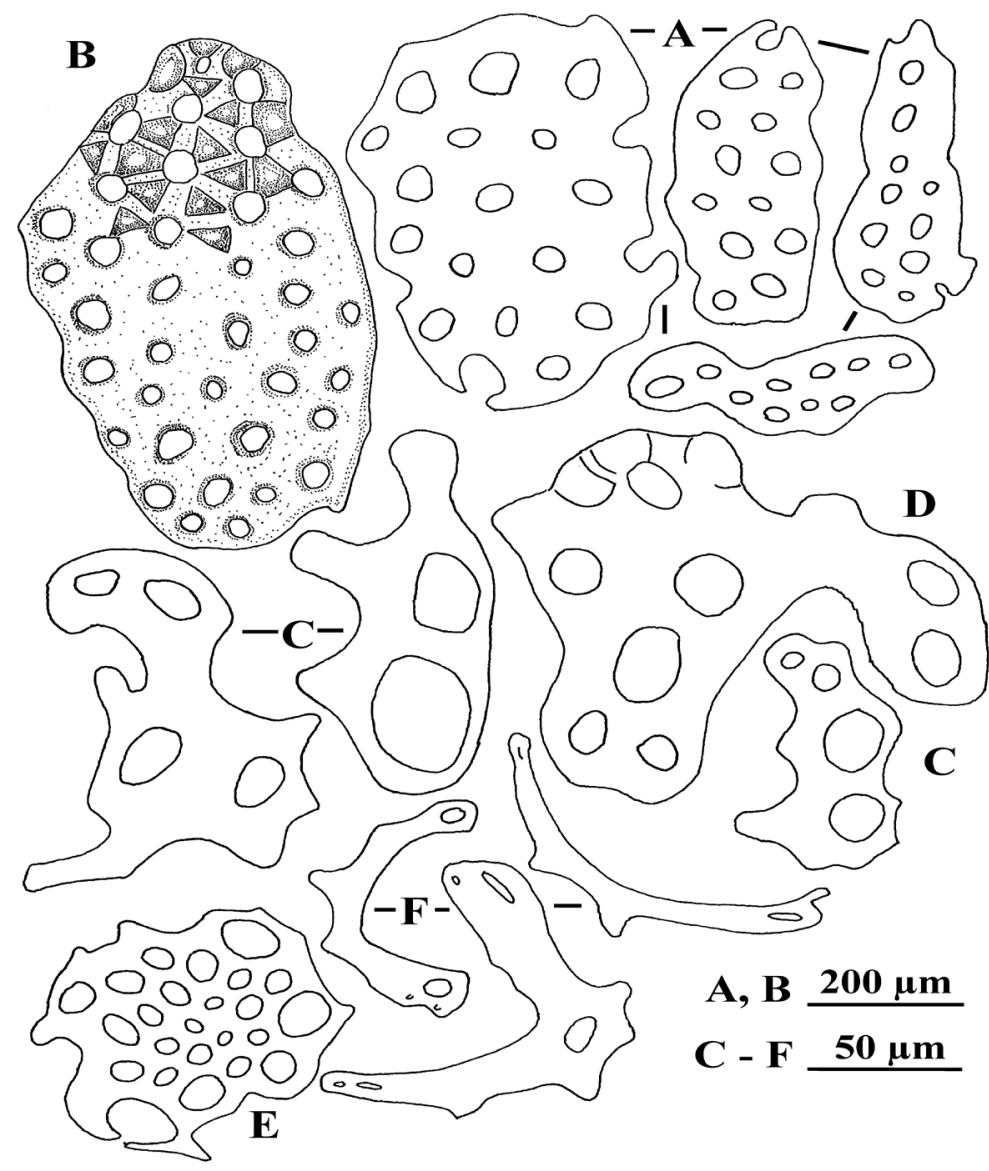

Figure 5. Mitsukuriella unusordo sp. nov. (holotype) A: smooth body wall scales. B: knobbed body wall scales. C-D: perforated plates of tube feet. E: end-plate of the tube feet. F: V-shaped rods from tube feet.

Figure 6. Mitsukuriella unusordo sp. nov. (holotype) Rods of the tentacles.

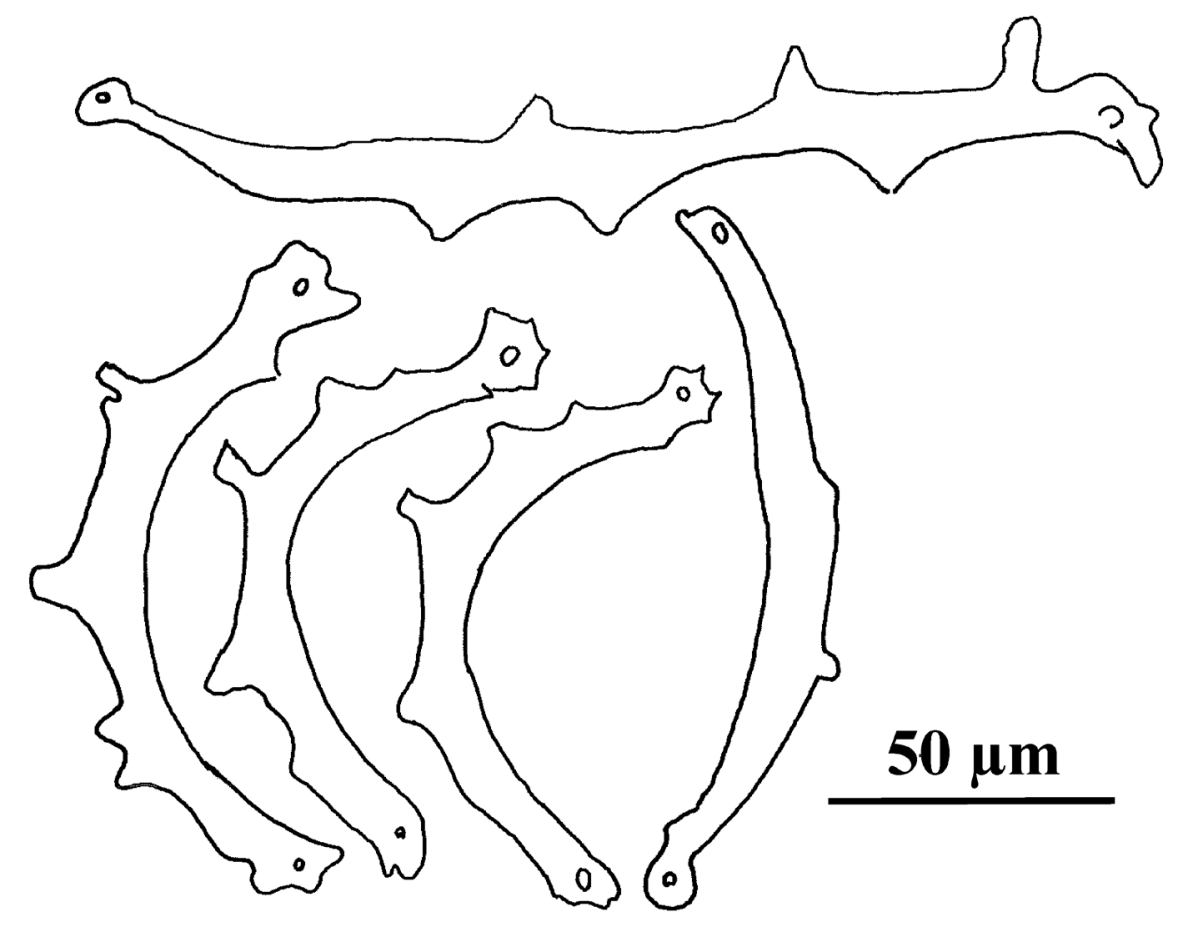




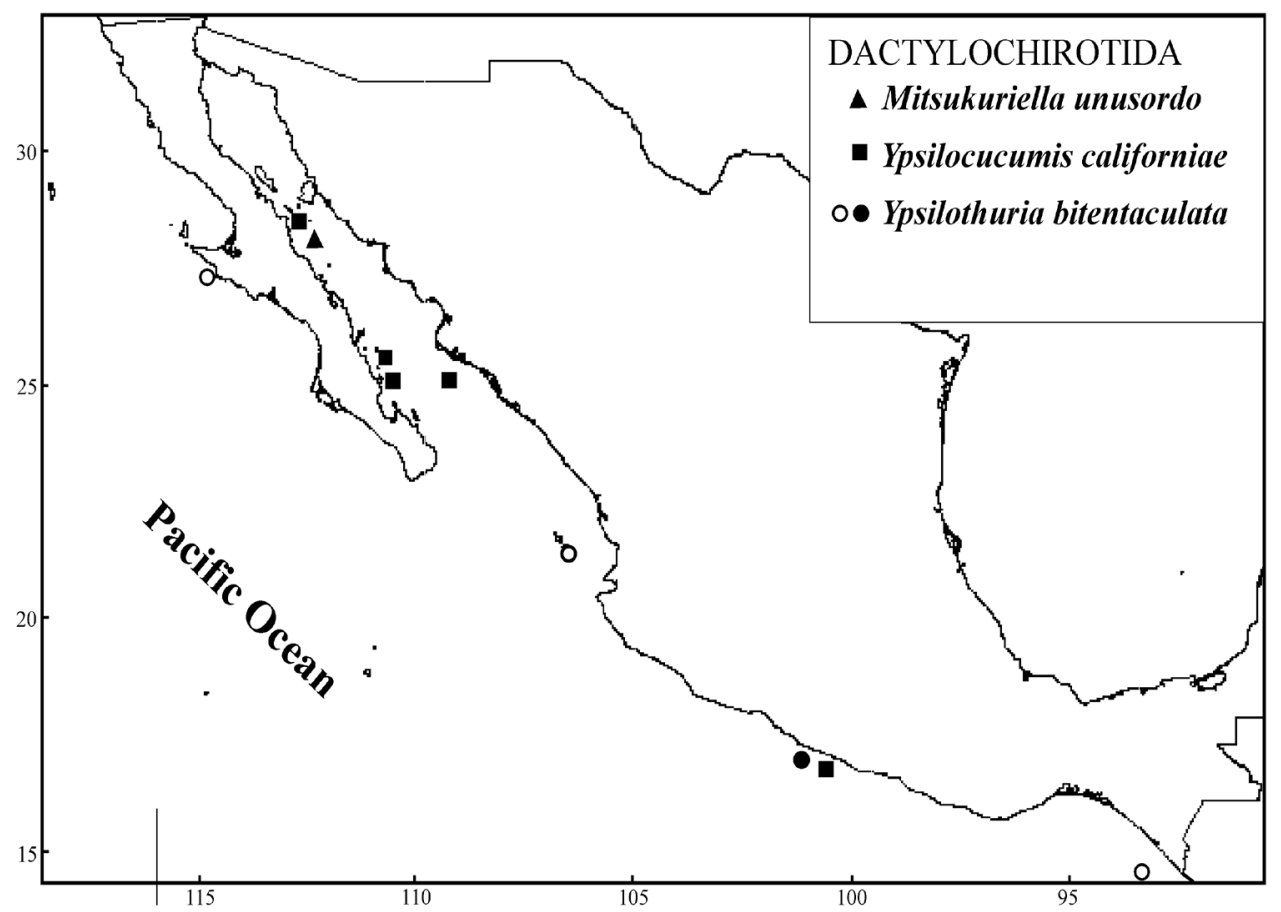

Figure 7. Distribution of examined species of Dactylochirotida off the Pacific coast of Mexico, including previous records (open symbols) and localities where material was collected (solid symbols).

Figure 8. Ypsilocucumis californiae nov sp. (holotype) A: calcareous ring (r: radial piece; ir: interradial piece); B: small body wall scales; $\mathrm{C}$ : large multilayered body wall scales; D: excentric spire of the large body wall scale; E-F: rods of the tentacles.

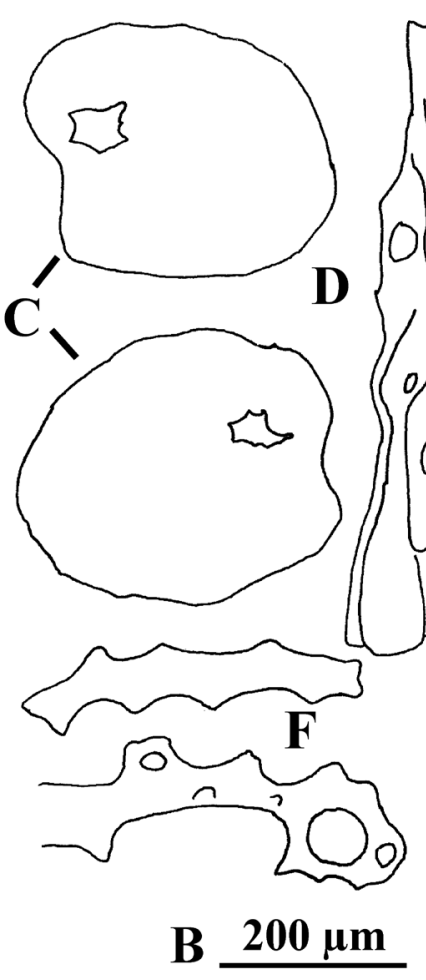

$\mathrm{D}, \mathrm{E}, \mathrm{F} \underline{100 \mu \mathrm{m}}$
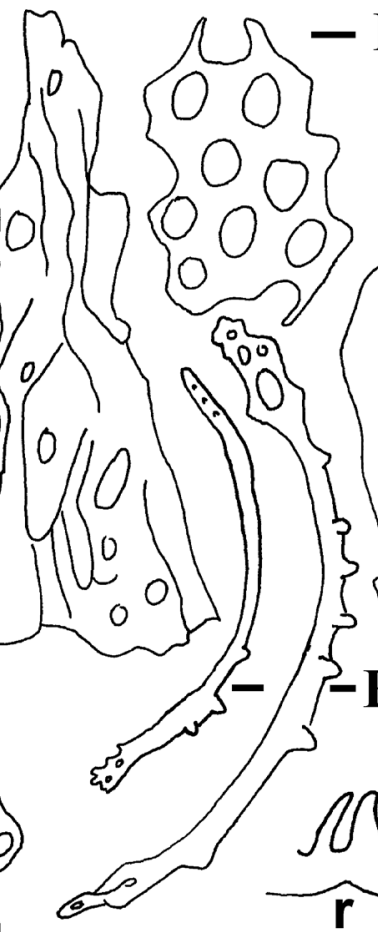

B

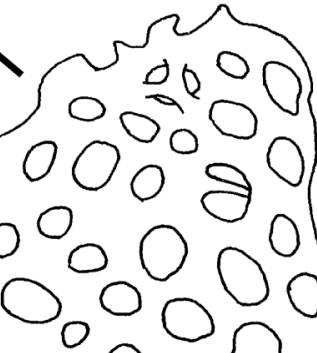
00 so 100 000 000 \}$_{3} 30$ 0
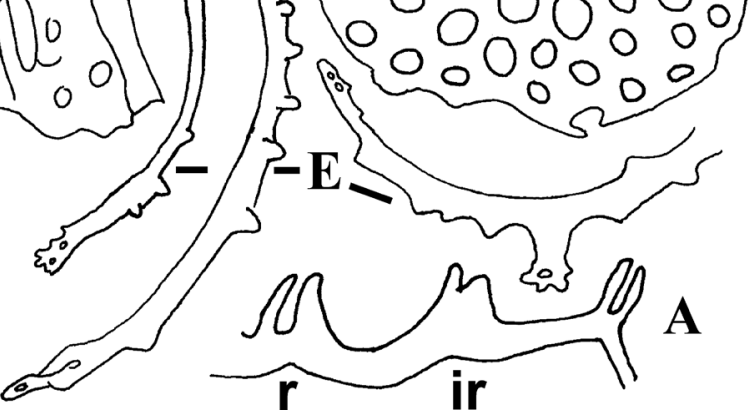

A $\underline{500 \mu m}$ 


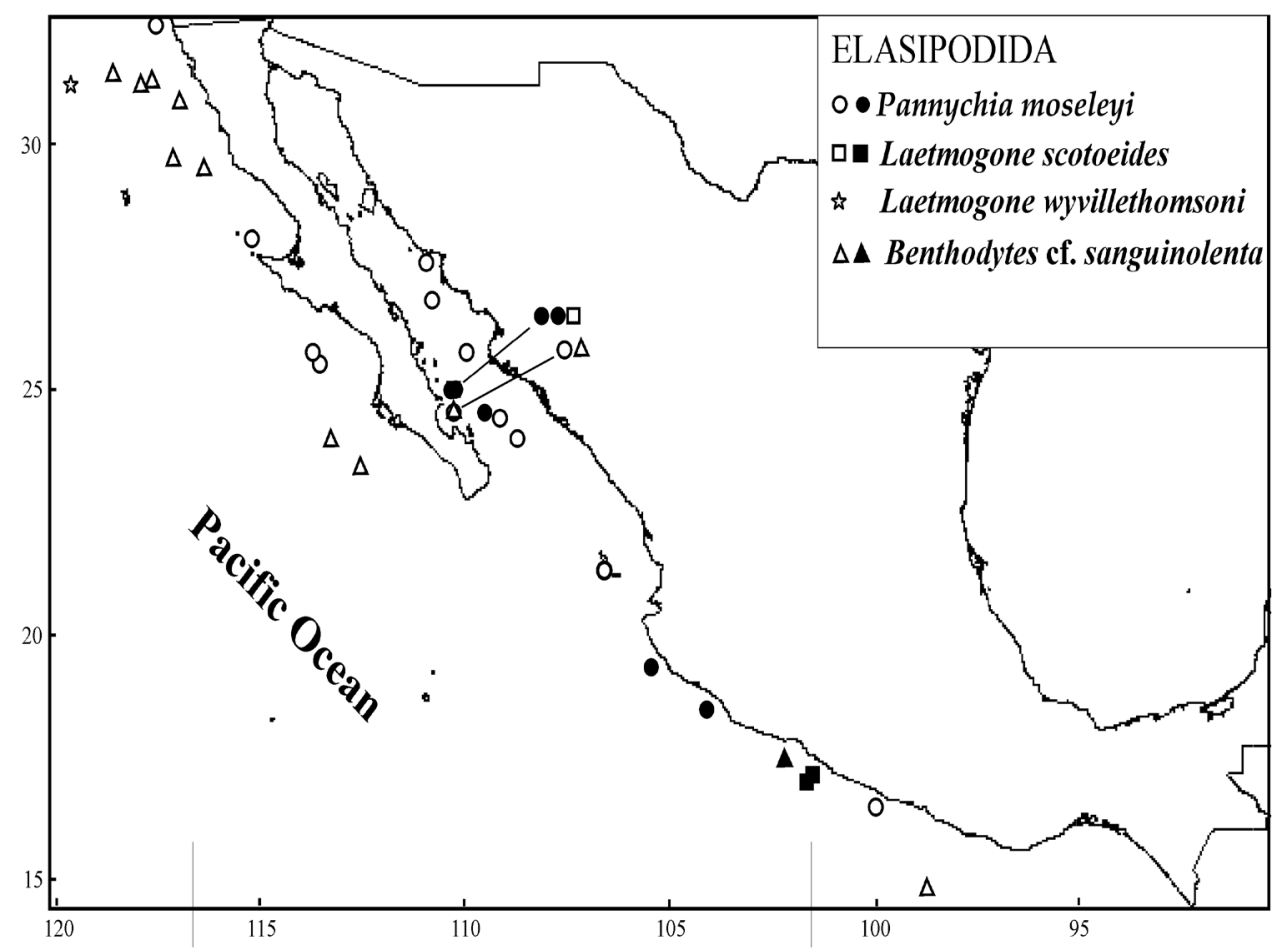

Figure 9. Distribution of examined species of Elasipoda off the Pacific coast of Mexico, including previous records (open symbols) and localities where material was collected (solid symbols).

Figure 10. Laetmogone scotoeides (H.L. Clark, 1913). A: large wheel of body wall. B: small wheels of the tube feet. C: large wheel of the tube feet. D: rods of the body wall and tube feet. E: irregular, branching rods of the tube feet end-plate.

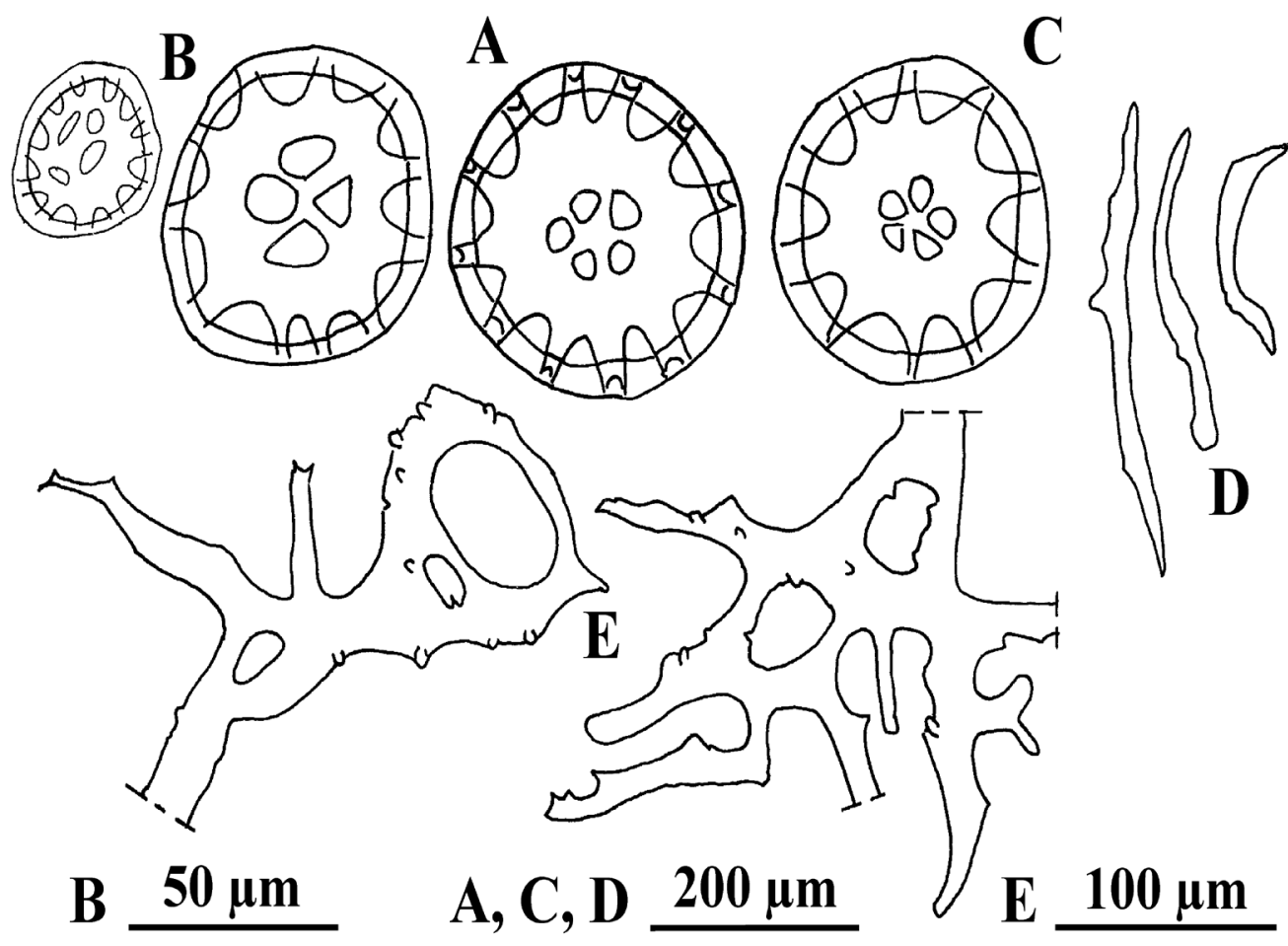




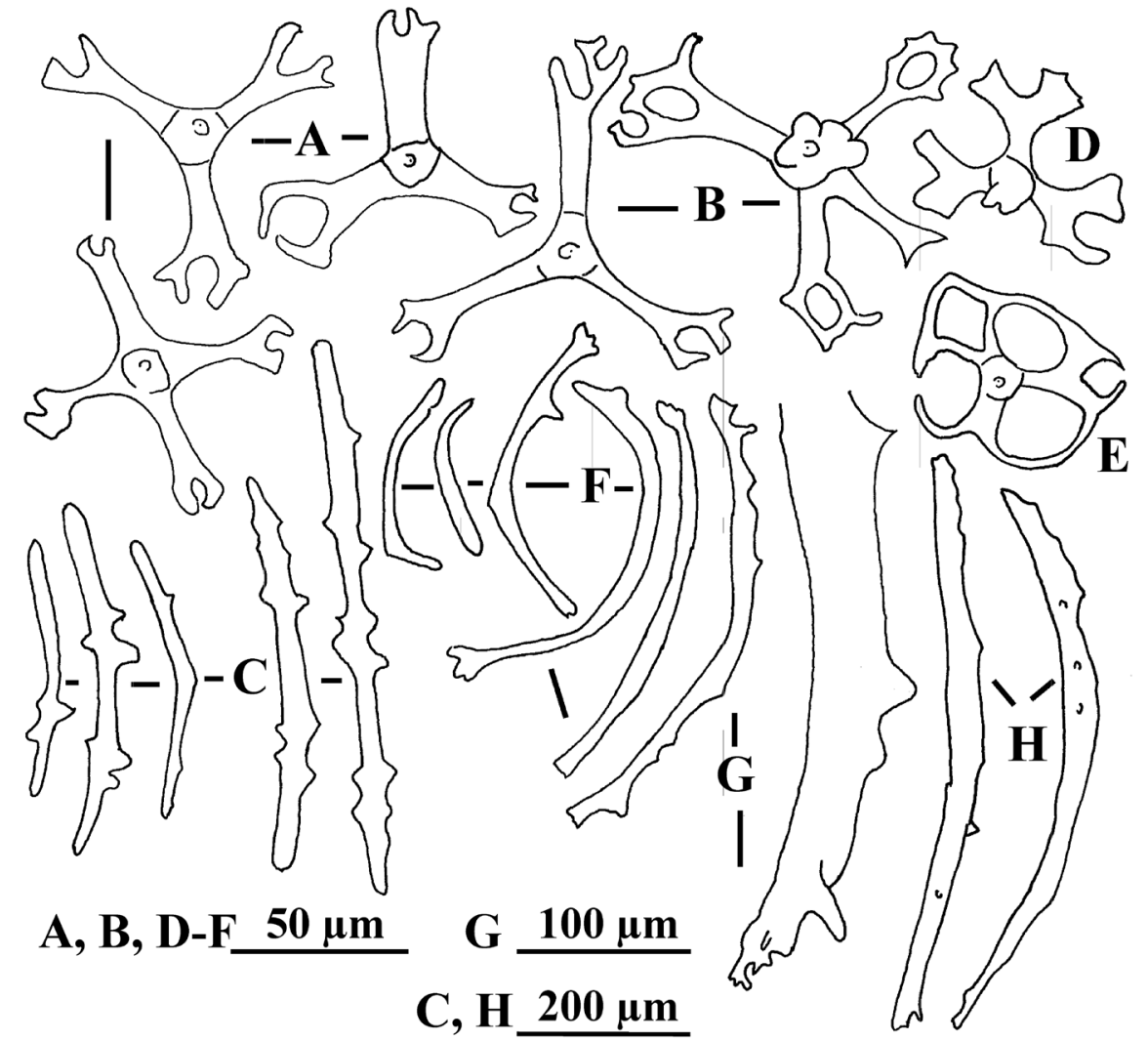

Figure 11. Synallactes alexandri Ludwig, 1893. A: cross-shaped ossicles from body wall. B: cross-shaped ossicles from dorsal papillae. C: rods of the tube feet. D: cross-shaped ossicle from tube feet. E: pseudo table of tube feet. F, G, H: rods of the tentacles.
Figure 12. Distribution of examined species of Aspidochirotida off the Pacific coast of Mexico, including previous records (open symbols) and localities where material was collected (solid symbols).

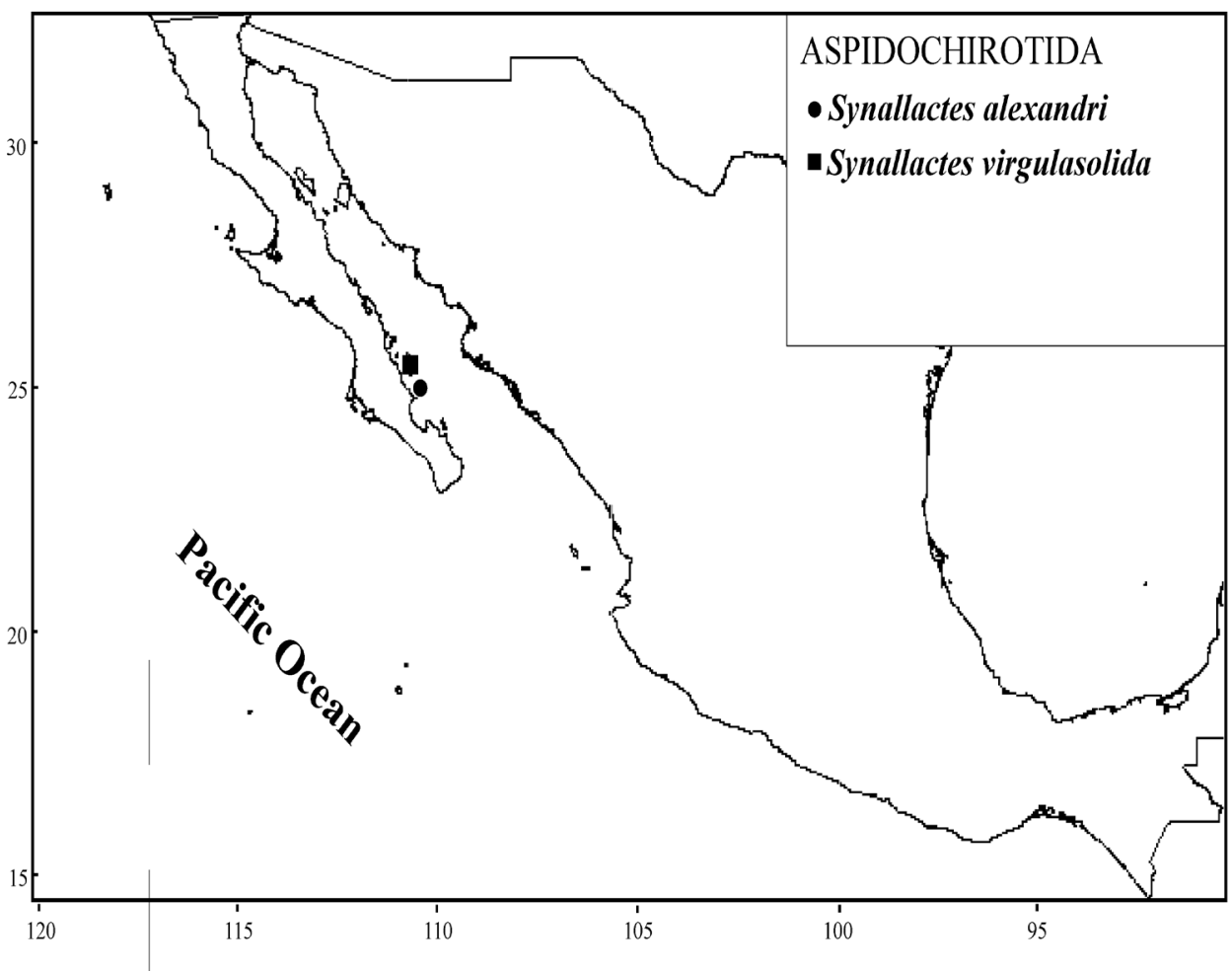




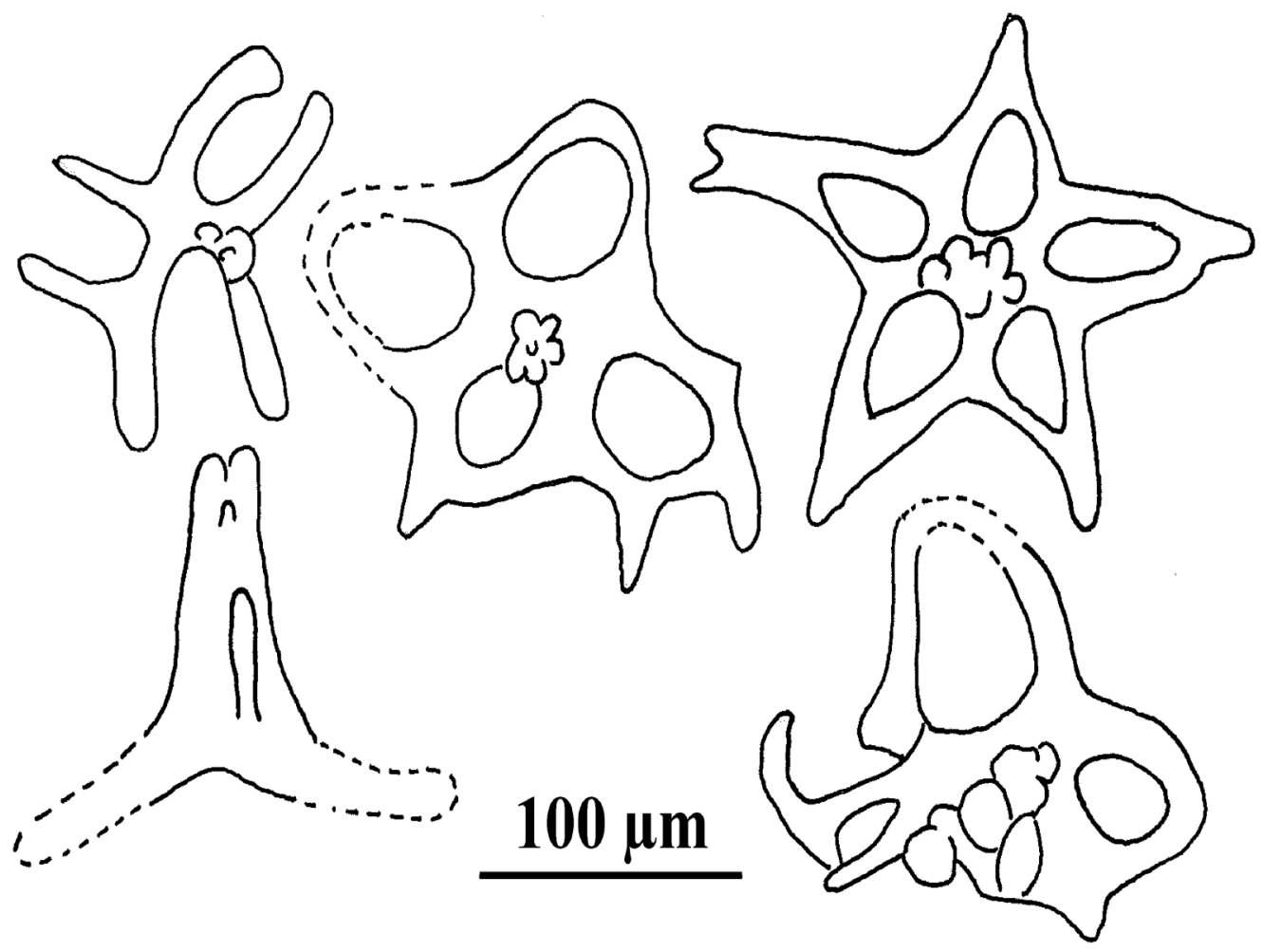

Figure 13. Molpadia intermedia (Ludwig, 1894). Tables of the tail.

Figure 14. Distribution of examined species of Molpadiida off the Pacific coast of Mexico, including previous records (open symbols) and localities were material was collected (solid symbols).

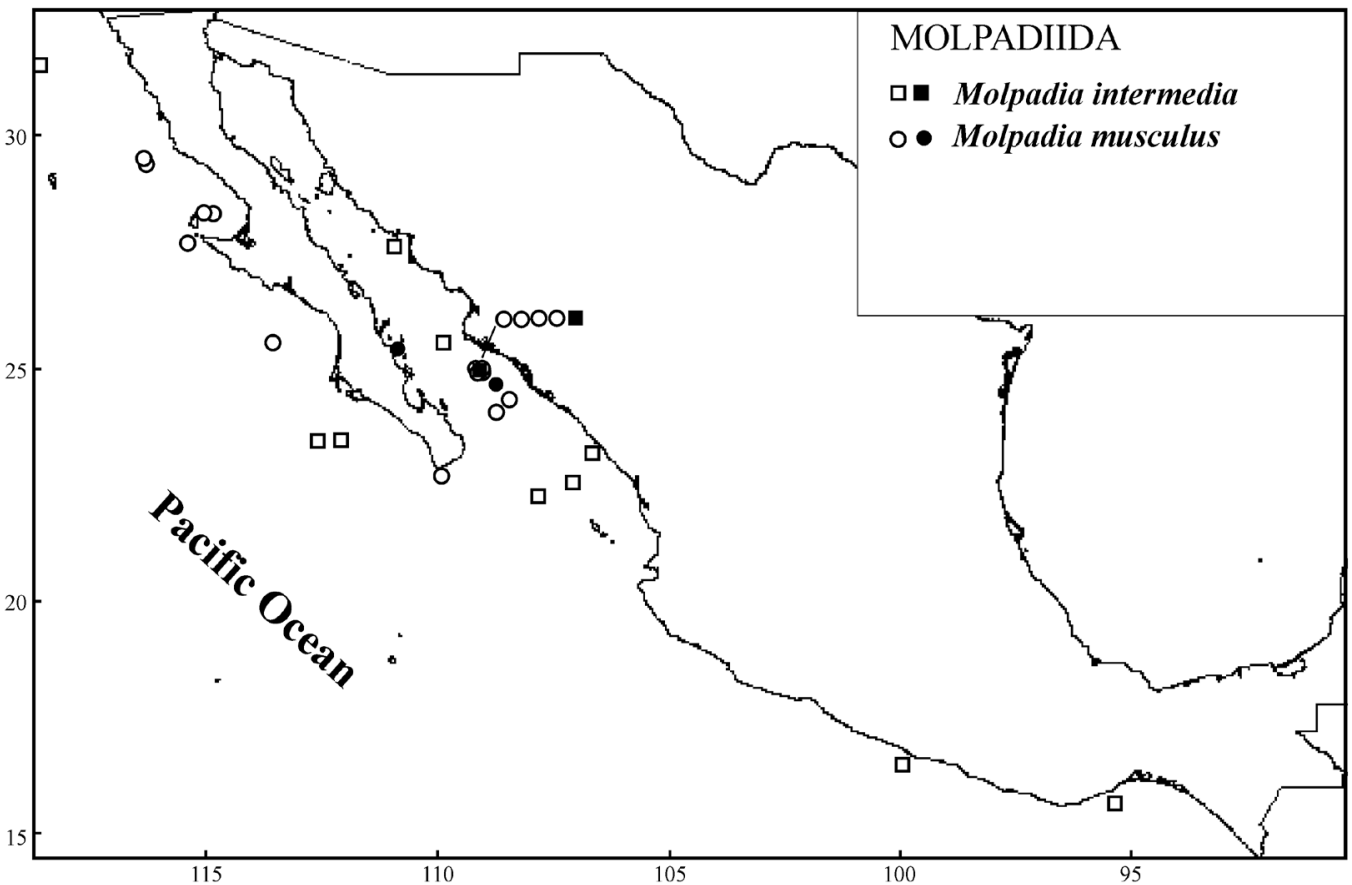


Appendix 1. Remarks concerning doubtful or erroneous depth records in Solís-Marín et al. (2009).

Cucumaria crax Deichmann, 1941, is reported by Solis-Marin et al. (2009) in depths of 8-549 m. According to Maluf (1988), this species occurs between 15 and $55 \mathrm{~m}$ depth. We could not locate a reference to the $549 \mathrm{~m}$ record. When the list of material cited by Solis-Marin et al. (2009; 3 records) is examined, the only option for this record seems to be the one of "Bahía Sta. María", 2456.3'N, $108^{\circ} 44.6^{\prime} \mathrm{W}$ (the 2 others are cited by Maluf, 1988). However, there is no citation of a cruise sampling at that depth in this area and, according to ecological data gathered in that area, bottom at ca $549 \mathrm{~m}$ depth is almost anoxic (Hendrickx and Serrano, 2010). In addition, plotting the latitude-longitude data on a map indicates that the "Sta. María" station actually corresponds to a depth of less than $200 \mathrm{~m}$.

Pseudocnus californicus (Semper, 1868), in 0-717 m (Solis-Marin et al. 2009). An intertidal to 190m species according to Maluf (1988). We were not able to locate a record at this depth. All records by Solis-Marin et al. (2009) are from intertidal or very shallow water; only 1 is from the same sample as previous species (i.e., C. crax; Bahía Sta. María), but the authors provide a distinct maximum depth range ( $717 \mathrm{~m}$ vs. $549 \mathrm{~m}$ for C. crax).

Holothuria leucospilota (Brands, 1835), in 0-695 m (Solis-Marin et al. 2009). An intertidal species according to Maluf (1988). According to Samyn and Massin (2003), deeper record is from $8 \mathrm{~m}$. We found no trace of a $695 \mathrm{~m}$ record in the Gulf of California or in the eastern Pacific for this species.

Parastichopus californicus (Stimpson, 1857), in 5-5 $640 \mathrm{~m}$ (Solis-Marin et al. 2009). From the intertidal to $180 \mathrm{~m}$ (Maluf, 1988) and to $216 \mathrm{~m}$ (Lambert, 1986). There seem to be no such depth in the Gulf of California. The 2 lots cited by Solis-Marin et al. (2009) are from San Benedito and Angel de la Guarda Islands, certainly from much shallow water. Also, the reference to Théel (1886) in the synonymy refers to Théel's "Challenger" contribution but it should be the "Blake" contribution. See "Referencias Bibliográficas" in Solis-Marin et al. (2009).

Chiridota aponocrita H.L. Clark, 1920, in 9-4 755 m (Solis-Marin et al. 2009). In the intertidal (Maluf 1988). Actually the data reported by Solis-Marin et al. (2009) correspond to 1 of the 2 Albatross stations where another species, Protankyra "abyssicola" (see H.L. Clark, 1920), was collected (top of page 125 in H.L. Clark, 1920). The depth range reported for Ch. aponocrita is therefore due to a confusion. 
